\title{
A Simple Geospatial Nutrient Budget Model for Assessing Forest Harvest Sustainability across Nova Scotia, Canada
}

\author{
Kevin Keys', Joshua D. Noseworthy², Jae Ogilvie², David L. Burton³, Paul A. Arp² \\ ${ }^{1}$ Nova Scotia Department of Natural Resources, Truro, Nova Scotia \\ ${ }^{2}$ Faculty of Forestry and Environmental Management, UNB, Fredericton, New Brunswick \\ ${ }^{3}$ Department of Environmental Sciences, Agricultural Campus, Dalhousie University, Truro, Nova Scotia \\ Email: arp1@unb.ca, kevin.keys@novascotia.ca
}

How to cite this paper: Keys, K., Noseworthy, J.D., Ogilvie, J., Burton, D.L. and Arp, P.A. (2016) A Simple Geospatial Nutrient Budget Model for Assessing Forest Harvest Sustainability across Nova Scotia, Canada. Open Journal of Forestry, 6, 420444.

http://dx.doi.org/10.4236/ojf.2016.65033

Received: June 14, 2016

Accepted: September 26, 2016

Published: September 29, 2016

Copyright $\odot 2016$ by authors and Scientific Research Publishing Inc. This work is licensed under the Creative Commons Attribution International License (CC BY 4.0).

http://creativecommons.org/licenses/by/4.0/

(c) (i) Open Access

\begin{abstract}
A geospatial GIS-linked spreadsheet model (Nutrient Budget Model-Nova Scotia: NBM-NS) was developed for Nova Scotia to assess the long-term sustainability of forest harvest scenarios as constrained by primary nutrient inputs and outputs due to atmospheric deposition, soil weathering, and leaching. Harvest scenarios refer to user-defined stand-specific removal rates of bole wood, bark, branches, and foliage, based on current or projected forest inventories. These scenarios are evaluated within the context of existing data layers for current climate (mean annual precipitation and air temperatures), atmospheric deposition ( $\mathrm{N}, \mathrm{S}, \mathrm{Ca}, \mathrm{Mg}, \mathrm{K}$ ), and soil/substrate types, supplemented by species-specific look-up tables containing expected biomass fractions and nutrient concentrations. This article introduces this model to assess relative site quality and limiting nutrients for red spruce and sugar maple across Nova Scotia. This is followed by an output comparison involving 25 spruce plantations whereby NBM-NS determinations derived using "default" soil survey data are compared with those derived using plantation-specific soil data. Model output shows that (i) Ca and $\mathrm{N}$ are the main growth-limiting nutrients across Nova Scotia, (ii) currently projected plantation yields are generally not sustainable on sites underlain by slowly weathering soils, (iii) current soil base cation contents are generally lower than what is reported in historic soil survey reports, and (iv) model results are expected to vary within the context of changing climate, acid deposition levels, and data accuracy.
\end{abstract}

\section{Keywords}

Forest Nutrition Management, Biomass Harvesting, Sustainable Forest Management, Forest Plantation Management 


\section{Introduction}

Although sustainable forest management can be defined in many ways, sustainability of forest harvesting is ultimately dependent on the availability of growth-limiting nutrients (Ågren, 1985; Sverdrup \& Rosen, 1998). Harvesting and acid depletion lead to nutrient losses from a site, thereby reducing soil/site nutrient pools (Tew et al., 1986). If these exports exceed primary nutrient inputs, then repeated harvesting coupled with soil acidification stress would be expected to cause nutrient deficiencies (de Vries et al., 1995; Oja \& Arp, 1996) leading to declines in forest health and productivity (Ouimet et al., 2001). Although the potential for productivity decline is usually associated with forest biomass or whole tree harvesting (e.g., Thiffault et al., 2011), nutrient deficiencies are also possible with more conventional stem-only harvesting if harvest demands are high or sites are nutrient poor.

In simple nutrient budget terms, demand refers to nutrients removed from a site through forest harvesting and acid depletion, whereas supply refers to nutrient inputs from atmospheric deposition and soil weathering (Moayeri, 2000). A sustainable balance is achieved when demand is less than or equal to supply in the context of a complete harvest rotation; i.e., all nutrients lost through harvesting and depletion need to be replenished before the next rotation comes into effect. In this regard, forest nutrient budgets can vary widely across landscapes based on differences in climate, atmospheric deposition, soil type, and vegetation type (Ranger \& Turpault, 1999).

Allometric relationships using traditional forest inventory data can be used to calculate harvest-based nutrient removals in considerable detail. This includes tracking species-specific nutrient removals by bolewood, bark, branch, and foliage biomass compartments (e.g., Freedman et al., 1986; Arthur et al., 1999). Atmospheric deposition, soil acidification, and weathering inputs can be estimated with regional survey datasets and maps (e.g., Arp et al., 2001; Ouimet et al., 2006; Nasr et al., 2010). Finally, necessary soil data can be acquired from general surveys or site-specific assessments.

This article describes a regional nutrient budget model (NBM-NS) developed for Nova Scotia, Canada that can be used (i) to estimate and map landscape and stand-level primary nutrient supplies in relation to modelled atmospheric deposition and soil weathering rates, and (ii) to relate these supplies to potential harvest demands from current or projected stand inventory data, with or without imposing acid rain induced soil acidification. This is followed by a case study showing how NBM-NS was used to assess the long-term nutrient sustainability of 25 spruce plantations across several soil and site types in central Nova Scotia within the context of currently available provincewide data layers for climate, atmospheric deposition, and soils.

\section{Methods}

NBM-NS is a geospatial, GIS-linked spreadsheet model that focuses on linking major nutrient and acid loading drivers, namely calcium $(\mathrm{Ca})$, magnesium $(\mathrm{Mg})$, potassium $(\mathrm{K})$, nitrogen $(\mathrm{N})$, and sulphur (S), to forest growth in terms of per hectare per year biomass accumulations. Only primary nutrient inputs and outputs are considered. 
Secondary nutrient cycling processes, while important, are assumed to only result in a temporal redistribution of nutrients within forest stands. Potential nutrient losses from episodic fires are also not considered because fires in actively managed forests are generally suppressed, while impacts of historic fires are, in part, reflected by current site/ soil conditions.

The following geospatial databases were used for NBM-NS input and ArcMap processing:

- Total mean annual atmospheric deposition coverage layers for $\mathrm{S}$ and $\mathrm{N}$, and wet atmospheric deposition coverage layers for $\mathrm{Ca}, \mathrm{Mg}$, and $\mathrm{K}$ were obtained from the National Atmospheric Chemistry Database and Analysis System (NATChem), Meteorological Service of Canada (Ro \& Vet 2002; $50 \mathrm{~km}^{2}$ resolution). Base cation layers were adjusted for total deposition using a series of wet:dry deposition ratios generated by way of a watershed study for southwestern Nova Scotia (Yanni, 1996; Yanni et al., 2000).

- Climate data coverages for mean annual precipitation rates and air temperature were obtained from Environment Canada's National Climate Archive (Canadian Daily Climate Data, 2004-2008; $10 \mathrm{~km}^{2}$ resolution; AAFC, 2009).

- Provincial forest inventory stand coverage was obtained from the Nova Scotia Department of Natural Resources.

- Provincial Soil Survey Reports and Maps were obtained from the Canadian Soil Information System (CanSIS) database from Agriculture and Agri-Foods Canada (http://sis.agr.gc.ca/cansis/publications/surveys/ns/index.html).

Soil parameters within NBM-NS include: (i) percent clay (\% Clay); (ii) percent organic matter (\% OM); (iii) percent coarse fragments (\% CF); (iv) bulk density (Db); (v) potential rooting depth (Depth); (vi) percent base saturation (\% BS); (vii) percent total nitrogen (\% N); (viii) effective (unbuffered) cation exchange capacity (CEC); (ix) Ca, $\mathrm{Mg}$, and $\mathrm{K}$ fractions on cation exchange sites; and (x) total cation exchange sites (CES). All these data were compiled or calculated for each soil series across Nova Scotia using available soil survey data (Appendix 1) and/or derived pedo-transfer functions (Noseworthy, 2011). Predicted data were then reviewed and adjusted, as needed, to match criteria in soil series descriptions and trends observed from approximately 1500 soil pits assessed for the Nova Scotia Forest Ecosystem Classification (FEC) project (Neily et al., 2013). For example, predicted \% Clay could not be outside the range defined for the soil series, and soil depth needed to be within the range found in related FEC plots. Final "default" soil values were then assigned to respective GIS soil series polygons mapped across the province.

Soil weathering rates in NBM-NS are estimated using the Clay Content method (Sverdrup et al., 1990; de Vries et al., 1992)—adjusted for Db, \% CF, and \% OM-which calculates the total rate of base cation weathering $\left(B C_{w e}^{0}\right)$ within a soil matrix as follows:

$$
\begin{aligned}
B C_{\text {we }}^{0}= & D b \operatorname{Depth}\left(1-\frac{C F}{100}\right) \operatorname{EXP}\left(\left(\frac{A}{(2.6+273)}\right)-\left(\frac{A}{(273+\text { Tann })}\right)\right) \\
& \times\left(\frac{\text { Class } X}{100}\right)\left(1-\frac{O M}{100}\right),
\end{aligned}
$$


where $D b$ is the soil bulk density $\left(\mathrm{g} \cdot \mathrm{cm}^{-3}\right)$, Depth is the soil rooting space depth $(\mathrm{cm})$, $C F$ is the soil coarse fragment content (\%), $A$ is the Arrhenius pre-exponential factor (3600 J.mol ${ }^{-1} .{ }^{\circ} \mathrm{C}^{-1}$; Sverdrup, 1990), the constant 273 is the conversion from degrees Celsius to Kelvin, 2.6 is a reference temperature for northern climates $\left({ }^{\circ} \mathrm{C}\right.$ ) (de Vries, 1991), Tann is the mean annual air temperature $\left({ }^{\circ} \mathrm{C}\right)$, and $O M$ is the soil organic matter content (\%). Class $X$ refers to soil texture dependent parent material class weathering estimations (de Vries, 1991) calculated as:

$$
\begin{gathered}
\text { Class } 1=56.7 \text { Clay }-0.32 \text { Clay }^{2}, \\
\text { Class } 2=500+53.6 \text { Clay }-0.18 \text { Clay }^{2}, \\
\text { Class } 3=500+59.2 \text { Clay, } \\
\text { Class } 4=1500+59.2 \text { Clay, }
\end{gathered}
$$

where Clay refers to average \% Clay.

Class 1 represents acidic substrates such as those comprised of sand, gravel, and glacial tills high in acidic rock (granite, quartzite, non-calcareous sandstones, etc.). Class 2 represents intermediate substrates such as marine sediments; medium to fine textured glacial tills derived from slates, shales, and mudstones; and medium to coarse textured tills containing less acidic rock than Class 1 . Class 3 represents (i) the more basic substrates such as gabbro and basalt dominated glacial tills, and (ii) nutrient-enriched alluvium deposits. Class 4 represents calcareous substrates such as limestone, gypsum, calcareous sedimentary deposits, and related tills.

All compiled and derived data layers were geospatially aligned and intersected with provincial forest inventory maps, using ArcMap procedures, to create a spatial ecounit layer that informs about mean annual atmospheric deposition rates (precipitation, $\mathrm{S}, \mathrm{N}$, $\mathrm{Ca}, \mathrm{Mg}, \mathrm{K}$ ), air temperature, tree species composition, soil conditions, and weathering rates for each mapped forest stand. Continuous raster data (deposition and temperature) were averaged for each ecounit. Where ecounits were associated with more than one soil series polygon, ecounit values were area-weighted by soil polygon composition.

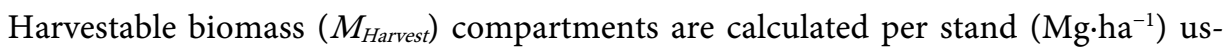
ing an oven-dry wood-density correct formulation:

$$
M_{\text {Harvest }}=\sum_{i=1}^{\infty}\left[\left(D_{i} V_{i}\right) \text { Bolewood }_{i}+\left(D_{i} V_{i}\right) \text { Bark }_{i}+\left(D_{i} V_{i}\right) \text { Branch }_{i}+\left(D_{i} V_{i}\right) \text { Foliage }_{i}\right]
$$

where subscript $i$ denotes each tree species in the stand (\%), $D_{i}$ represents species-specific stem densities taken from Gonzalez (1990), $V_{i}$ is the total merchantable volume of each species in the stand $\left(\mathrm{m}^{3} \cdot \mathrm{ha}^{-1}\right)$, and Bolewood, Bark, Branch, and Foliage denote the Lambert et al. (2005) generated biomass fractions, each prorated to stem biomass as follows:

$$
\text { Compartment biomass } / \text { Stem biomass }=A_{i} \exp \left[B_{i} \ln \left(D B H_{i}\right)\right]
$$

where $D B H_{i}$ refers to diameter at breast height (tree of average basal area), and $\mathrm{A}_{i}$ and $\mathrm{B}_{i}$ are species and compartment-specific biomass proration numbers (Appendix 2, Noseworthy, 2011). 
Nutrient losses due to harvesting $\left(X_{\text {Harvest }}\right)$, expressed in eq $\cdot \mathrm{ha}^{-1}$, are calculated from:

$$
\begin{aligned}
X_{\text {Harvest }}= & \sum_{i=1}^{\infty}\left[( D _ { i } V _ { i } ) \left(\text { Stem }_{i}\left[X_{\text {Bolewood }_{i}}\right)+\left(D_{i} V_{i}\right)\left(\text { Bark }_{i}\left[X_{\text {Bark }}\right]_{i}\right)\right.\right. \\
& \left.+\left(D_{i} V_{i}\right)\left(\text { Branch }_{i}\left[X_{\text {Branch }}\right]_{i}\right)+\left(D_{i} V_{i}\right)\left(\text { Foliage }_{i}\left[X_{\text {Foliage }}\right]_{i}\right)\right] 10^{6} / X_{\text {g/eq }}
\end{aligned}
$$

where $X$ refers to one of four nutrients $(\mathrm{Ca}, \mathrm{Mg}, \mathrm{K}, \mathrm{N}),\left[X_{i}\right]$ refers to biomass nutrient fraction, and the subscript $\mathrm{g} / \mathrm{eq}$ denotes the equivalent weight of element $X(\mathrm{Ca}=20$, $\left.\mathrm{Mg}=12.2, \mathrm{~K}=39.1, \mathrm{~N}=14 ; \mathrm{g} \cdot \mathrm{eq}^{-1}\right)$. Listed in Appendix 2, by selected tree species, are (i) oven-dried bole wood densities, (ii) stem-based A and B biomass proration coefficients by tree compartment, and (iii) biomass $\mathrm{N}, \mathrm{Ca}, \mathrm{Mg}$, and $\mathrm{K}$ concentrations per biomass compartment.

Total uptake of base cations $\left(B C_{u p}\right)$ and nitrogen $\left(N_{u p}\right)$ for each forest site were calculated from:

$$
B C_{u p}=\left(C a_{H S}+M g_{H S}+K_{H S}\right) / A g e \text { and } N_{u p}=N_{H S} / \text { Age },
$$

where the subscript $H S$ denotes user-determined harvest scenarios (i.e., the proportion of bolewood, bark, branch and foliage removed) and Age is the average stand age (years). All uptake equations are expressed in eq $\cdot \mathrm{ha}^{-1} \cdot \mathrm{yr}^{-1}$.

Nutrient deficiencies refer to the difference between nutrient inputs (atmospheric deposition and weathering) and nutrient outputs due to harvesting. A positive value (gain) indicates a sustainable harvest rate, while a negative value (deficit) indicates an unsustainable harvest rate (assuming repeated harvests under the same harvest scenario and stand/site conditions). For nitrogen, potential gains or deficits are estimated from $N_{d e f}=N_{d e p}-N_{u p}$. For base cations, potential gains or deficits are estimated from $X_{\text {def }}=$ $X_{d e p}+X_{w e}-X_{u p}$, with $X$ referring to $\mathrm{Ca}, \mathrm{Mg}$, or $\mathrm{K}$. All gains or deficits are expressed in eq $\cdot \mathrm{ha}^{-1} \cdot \mathrm{yr}^{-1}$.

In terms of base and acid cation leaching due to the combination of atmospheric deposition and vegetative uptake, it follows that:

$$
B C_{l e}=B C_{d e p}+B C_{w e}-B C_{u p},
$$

with subscripts dep, we, up and le referring to atmospheric deposition, soil weathering, uptake by vegetation, and leaching, respectively. All terms are expressed in eq.ha $\mathrm{h}^{-1} \cdot \mathrm{yr}^{-1}$.

The base cation leaching rate for upland forest soils was estimated from the law of mass action and charge conservation given by:

$$
K_{e x c h}=\frac{C E S-B C+\Delta x}{B C-\Delta x} \frac{B C_{l e}+\Delta x}{A C_{l e}-\Delta x}
$$

where $K_{\text {exch }}$ is the cation exchange ratio (set at 10 in order to reflect the adsorption preference of mineral soil surfaces for $\mathrm{H}^{+}$and $\mathrm{Al}^{3+}$ over adsorption of competing base cations-NEG-ECP, 2001; Nasr et al., 2010), CES refers to the sum of soil cation exchange sites (eq.ha ${ }^{-1}$ ), $B C$ is the sum of exchangeable soil base cations (eq.ha ${ }^{-1}$ ), $\Delta \mathrm{x}$ is the annual exchange of acid to base cations (leaching or accumulation) that shifts base saturation from the current state $(B S)$ to the final state $\left(B S_{f}\right) . B C_{l e}$ and $A C_{l e}$ are the base 
and acid cation leaching rates, with $A C_{l e}$ denoting hydrogen $\left(\mathrm{H}^{+}\right)$and aluminum $\left(\mathrm{Al}^{3+}\right)$ ions given by:

$$
A C_{l e}=S_{\text {dep }}+N_{\text {dep }}-N_{u p}+B C_{u p}=\frac{1}{K_{\text {exch }}} \frac{C E S-B C}{B C} B C_{l e},
$$

and $S_{d e p}$ denoting atmospheric $\mathrm{S}$ deposition. For soils with $A C_{l e}$ and $B C_{l e}<B C$, one obtains:

$$
\Delta x \approx \frac{100\left(B S-B S_{f}\right)}{B S B S_{f}\left(K_{\text {exch }}-1+100 / B S\right)} B C_{l e},
$$

with $B S$ and $B S_{f}$ as \%base saturations when $\Delta x \neq 0$ (i.e., current base saturation)and when $\Delta x=0$ (i.e., final base saturation), with $B S=100 B C / C E S$ and:

$$
B S_{f}=\frac{100}{1+K_{\text {exch }} A C_{l e} / B C_{l e}} .
$$

Sustainability of a harvest scenario is determined by way of the Sprengel-Liebig Law of the Minimum (van der Ploeg et al., 1999). This is related to (i) harvest deficiencies alone or (ii) in combination with acid-induced base cation depletion estimates:

$$
\begin{aligned}
& \min \left[N_{d e f}^{\text {Export }}, C a_{d e f}^{\text {Export }}, M g_{\text {def }}^{\text {Export }}, K_{\text {def }}^{\text {Export }}, 0\right], \underline{\text { or }} \\
& \min \left[N_{d p l+d e f}^{\text {Export }}, C a_{d p l+d e f}^{\text {Export }}, M g_{d p l+d e f}^{\text {Export }}, K_{d p l+d e f}^{\text {Export }}, 0\right],
\end{aligned}
$$

where $\min [\ldots]$ selects the growth-limiting nutrient for each stand. Each harvest scenario is considered sustainable when minimum values as evaluated above are greater than 0. A sustainable harvest rate, expressed as sustainable mean annual increment, i.e., SusMAI, in $\mathrm{m}^{3} \cdot \mathrm{ha}^{-1} \cdot \mathrm{yr}^{-1}$ of solid wood) is then derived based on (i) the annual input of the most limiting nutrient, (ii) the mass-weighted nutrient concentration per harvested biomass, and (iii) tree species composition.

For the plantation survey (25 spruce plantations, Figure 1, Table 1), soils were sampled during fall (2012) from three representative locations in each plantation based on visual assessment of ground conditions (distance between plots was about $100 \mathrm{~m}$ or

Table 1. Summary of sampled soils and plantations.

\begin{tabular}{cccc}
\hline Soil series & Plantations & Spruce species & Age range (yrs) \\
\hline Bridgewater & 2 & white/black & $7-16$ \\
Cobequid & 4 & white/black/red & $8-21$ \\
Halifax & 4 & white/black & $6-18$ \\
Millbrook & 4 & white/black & $5-12$ \\
Perch Lake & 3 & white/Norway & $5-16$ \\
Queens & 4 & white/black/Norway & $6-28$ \\
Thom & 3 & white/red & $7-12$ \\
Diligence & 1 & white & $4-8$ \\
\hline
\end{tabular}

Note: White spruce (Picea glauca), black spruce (Picea mariana), red spruce (Picea rubens), Norway spruce (Picea abies). 


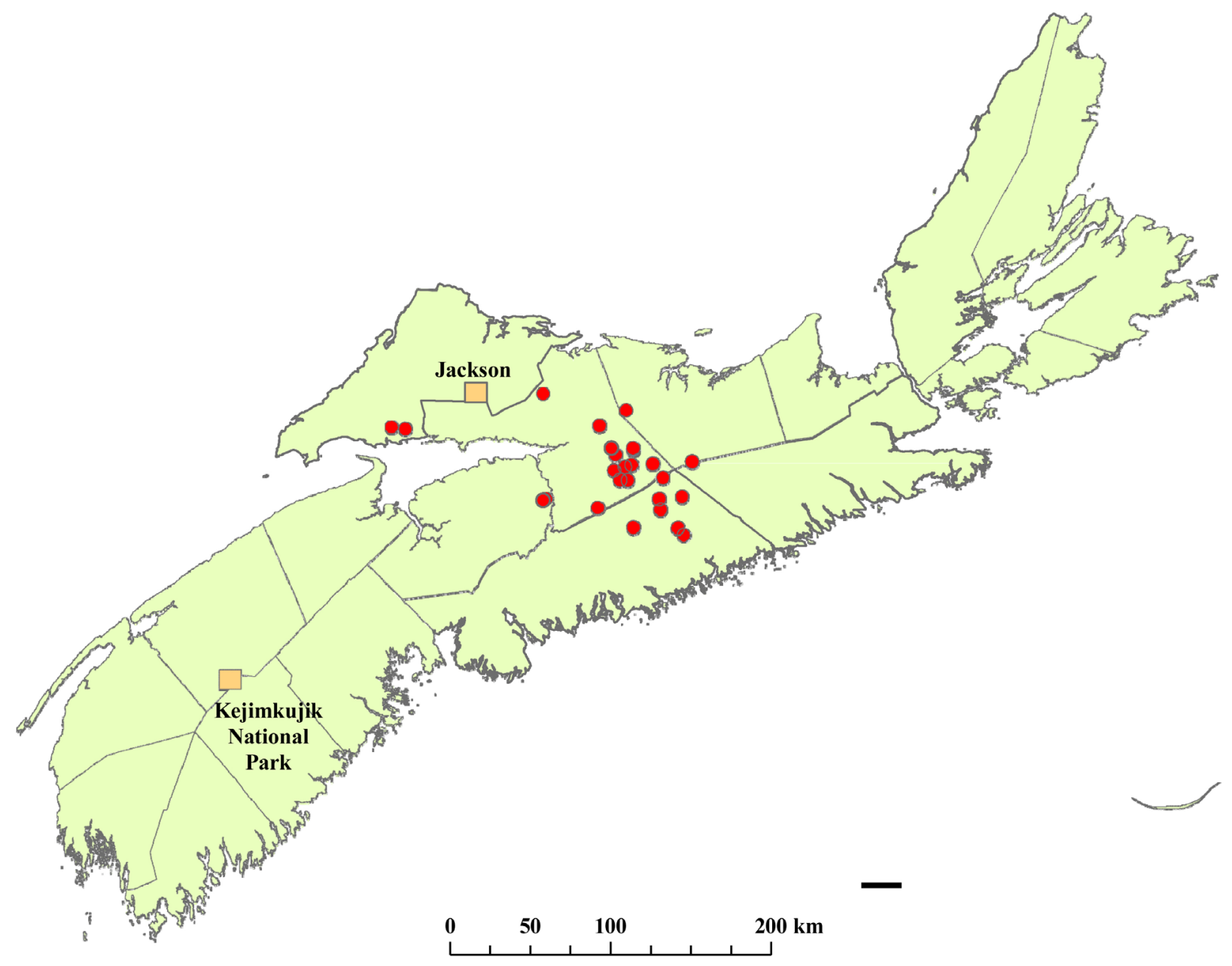

Figure 1. Case study plantation locations in central Nova Scotia, also showing the NATChem database locations for the CAPMon atmospheric depostion monitoring stations at Kejimkujik National Park and Jackson.

more). Pits were shovel-excavated and samples collected at two depths (approximately $0-15 \mathrm{~cm}$ and $30-45 \mathrm{~cm}$ ) for chemical and texture analysis. A soil corer was used to collect bulk density samples at these same depths. Visual estimates of potential soil rooting depth and coarse fragment volume were also recorded for each pit.

Soil samples were analyzed individually for chemistry and bulk density, and were pooled by plantation and depth for texture analysis. All chemical analyses were carried out by Analytical Services, Nova Scotia Department of Agriculture using standard in-house procedures (i) Mehlich 3 extraction followed by ICP analysis for base cations, (ii) LECO combustion for $\mathrm{N}$, (iii) loss-on-ignition at $450^{\circ} \mathrm{C}$ for 1 hour for $\mathrm{OM}$, and (iv) summation of base cations and exchangeable acidity for BS and CEC. Clay content (hydrometer method) and $\mathrm{Db}$ analyses (CF corrected) were carried out at Dalhousie University Agricultural Campus in Truro, NS. Chemical data were expressed on an area basis using measured bulk density before calculating final average values for each plantation soil. 


\section{Results and Discussion}

\subsection{Model Projections across Nova Scotia}

Total atmospheric deposition maps for S, N, Ca, Mg, and $\mathrm{K}$ are shown in Figure 2. Nitrogen $(\mathrm{N})$ and $\mathrm{S}$ deposition follow a west-east gradient (high to low) directly related to inputs from the northeast United States. Base cation trends are more variable, with Ca

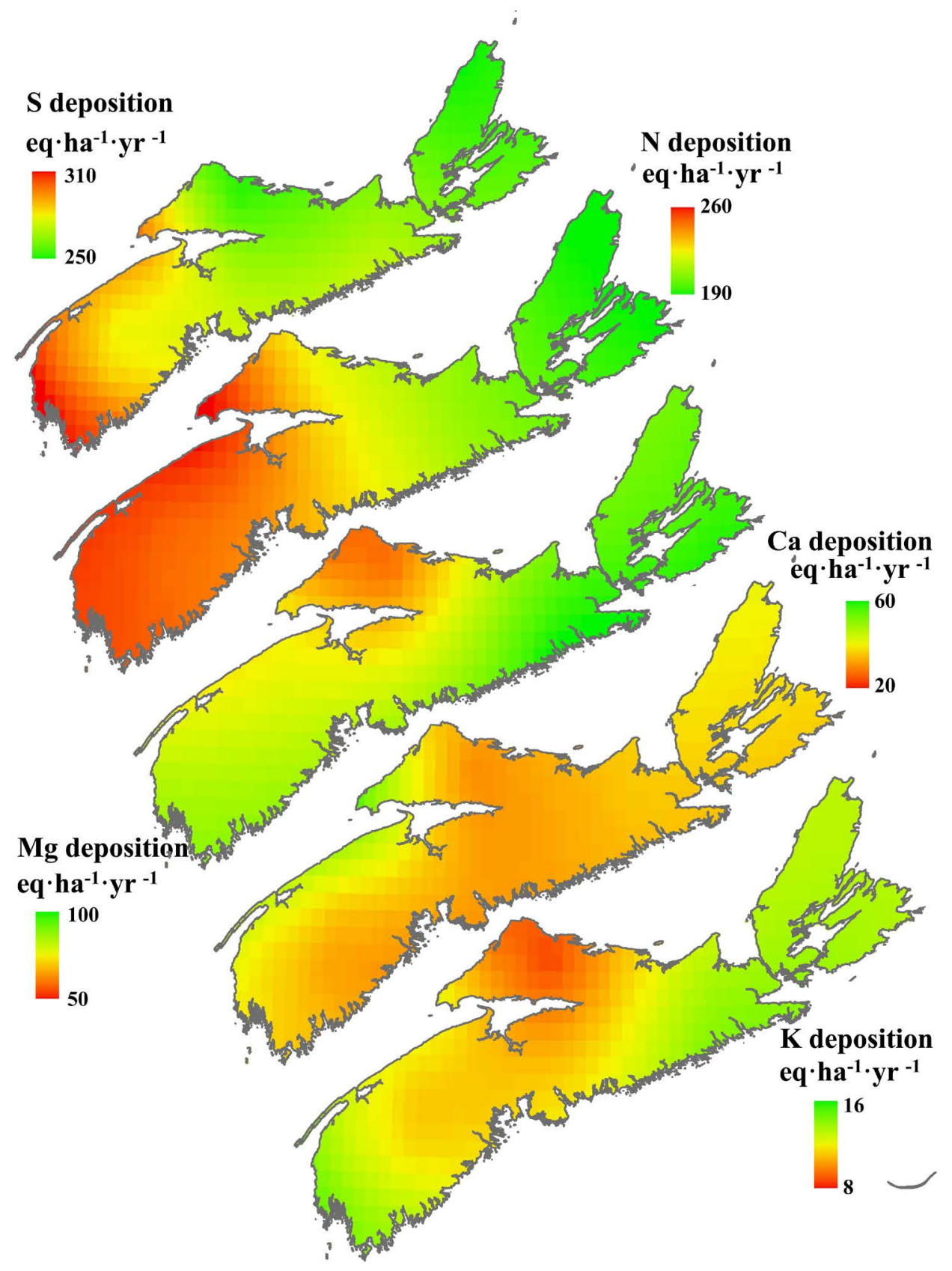

Figure 2. Estimated wet deposition rates for sulphate $\left(\mathrm{SO}_{4}^{2-}\right)$, nitrate $\left(\mathrm{NO}_{3}^{-}\right)$, ammonium $\left(\mathrm{NH}_{4}^{+}\right)$, magnesium $\left(\mathrm{Mg}^{2+}\right)$, calcium $\left(\mathrm{Ca}^{2+}\right)$, and potassium $\left(\mathrm{K}^{+}\right)$based on the National Atmospheric Chemistry Database and Analysis System (NATChem) dataset. 
deposition being highest along the northwest (Bay of Fundy) coast and northern Cape Breton Island, and lowest along the Atlantic coast and central mainland. Deposition patterns for $\mathrm{Mg}$ and $\mathrm{K}$ are relatively the same with the lowest levels found in north central parts of the province, increasing eastward into Cape Breton and (to a lesser extent) along the southwest coast. Figure 3 presents a range of default soil data determined or derived from provincial soil survey reports (\% clay, \% carbon, weatherability class), or based on more recent forest soil assessments (soil depth, \% base saturation). These maps show the range of soil conditions across Nova Scotia that influence site productivity.

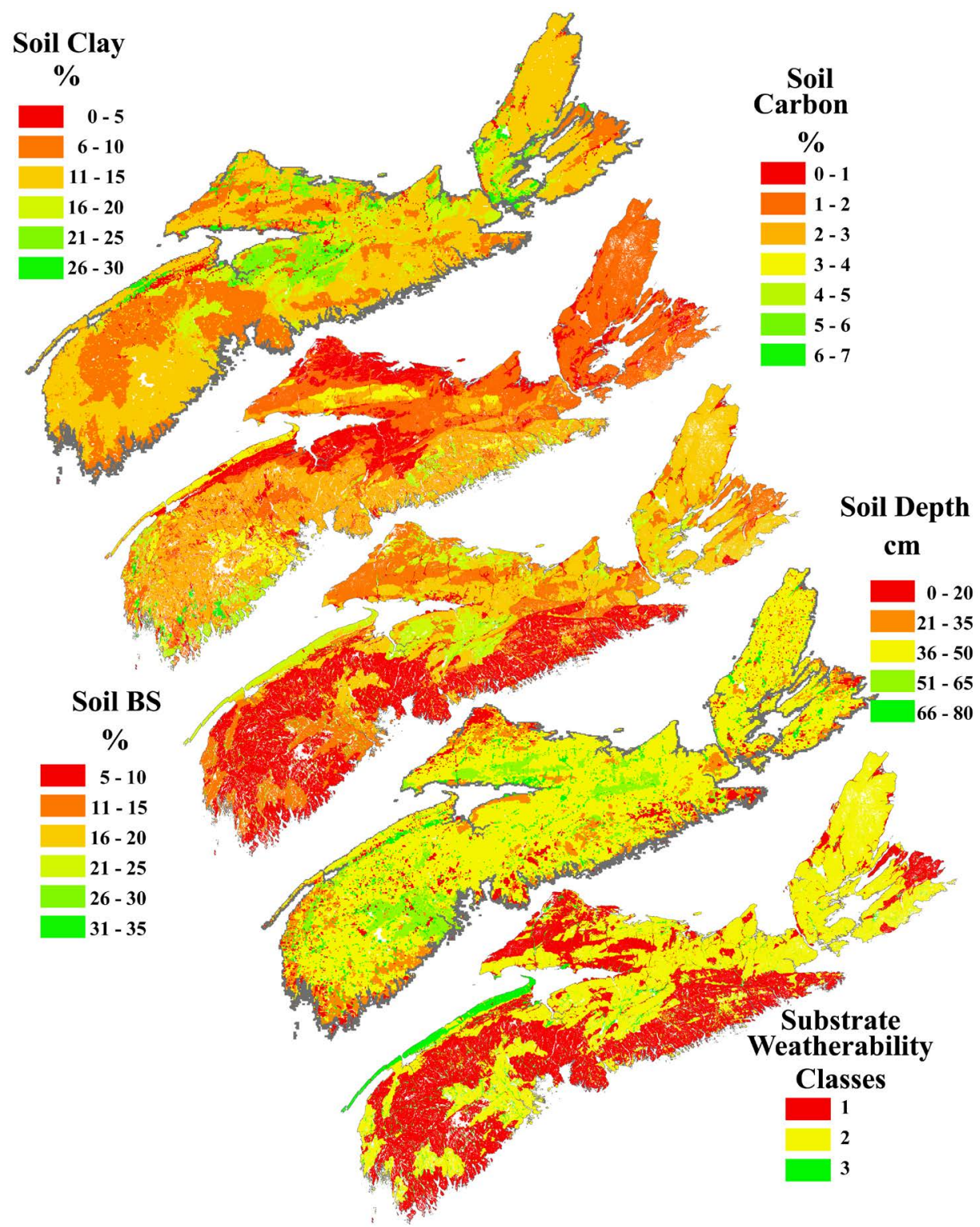

Figure 3. Distribution of soil properties (clay \%, carbon \%, base saturation \%, soil depth) and assigned soil substrate weatherability classes for Nova Scotia. Maps do not include water or organic soil. Note: Soil BS \% estimates are based on current available data, not historic soil survey data. 
To compare relative site productivity across the province based on default soil data, atmospheric deposition, and weathering inputs (without the confounding influence of variable tree cover), NBM-NS was run assuming all stands had the same species and stocking levels. One run assumed 80-year-old red spruce (Picea rubens) with qdbh of 20 $\mathrm{cm}$ and $60 \%$ stocking with an average merchantable volume of $247 \mathrm{~m}^{3} \cdot \mathrm{ha}^{-1}$ (Figure 4). The resulting estimates for sustainable mean annual increment (SusMAI) values ranged from less than 3.0 to more than $8.0 \mathrm{~m}^{3} \cdot \mathrm{ha}^{-1} \cdot \mathrm{yr}^{-1}$ (Figure 4). These values were mainly driven by soil characteristics and substrate type, with the lowest values associated with very coarse, acidic (Class 1), shallow soils; and the highest with deeper, medium to fine-textured (Class 2 and higher) soils. SusMAI values were also modified by atmospheric deposition, especially where $\mathrm{N}$ was calculated to be the growth-limiting nutrient. For example, estimated red spruce SusMAI on Gibraltar soil (a well-drained, coarsetextured, Class 1 soil limited by Ca) only ranged from 5.2 to $5.4 \mathrm{~m}^{3} \cdot \mathrm{ha}^{-1} \cdot \mathrm{yr}^{-1}$, whereas

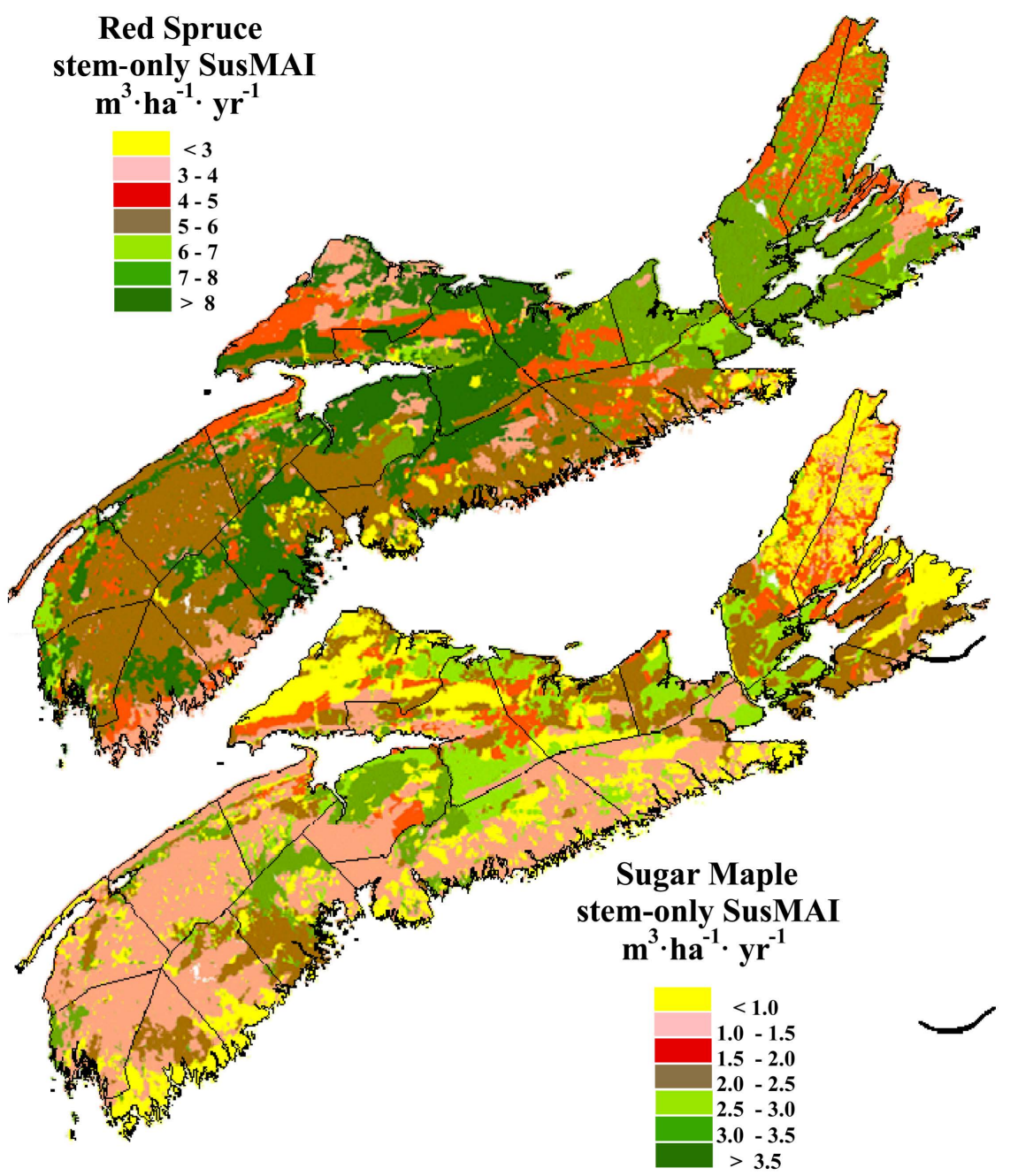

Figure 4. Predicted sustainable mean annual increment (SusMAI) across Nova Scotia generated by the NBM-NS model assuming default soil conditions and uniform red spruce (top) and sugar maple (bottom) cover. 
values on Queens soil (an imperfectly drained, fine-textured Class 2 soil limited by $\mathrm{N}$ ) ranged from 7.3 to $9.0 \mathrm{~m}^{3} \cdot \mathrm{ha}^{-1} \cdot \mathrm{yr}^{-1}$.

Another run assuming uniform cross-province coverage of 80-year-old sugar maple (Acer saccharum) with qdbh of $22 \mathrm{~cm}, 60 \%$ stocking, and average merchantable volume of $210 \mathrm{~m}^{3} \cdot \mathrm{ha}^{-1}$ resulted in estimated SusMAI values ranging from less than 1.0 to more than $3.5 \mathrm{~m}^{3} \cdot \mathrm{ha}^{-1} \cdot \mathrm{yr}^{-1}$ (Figure 4). Note: As a rule of thumb, hardwood MAI in Nova Scotia is about half that of softwood on the same site due to differences in growth form and basal area capacity (NSDLF, 1990; McGrath, 2011). Estimated SusMAI trends for sugar maple and red spruce mainly differ by growth-limiting nutrient, with $\mathrm{Ca}$ being more growth limiting for sugar maple than for red spruce (Figure 5) because of higher Ca demands (Appendix 2). The strip of K-limited area along the northwest (Bay of Fundy) coast was mainly associated with shallow Rossway soils on thin glacial till deposits over basalt bedrock.

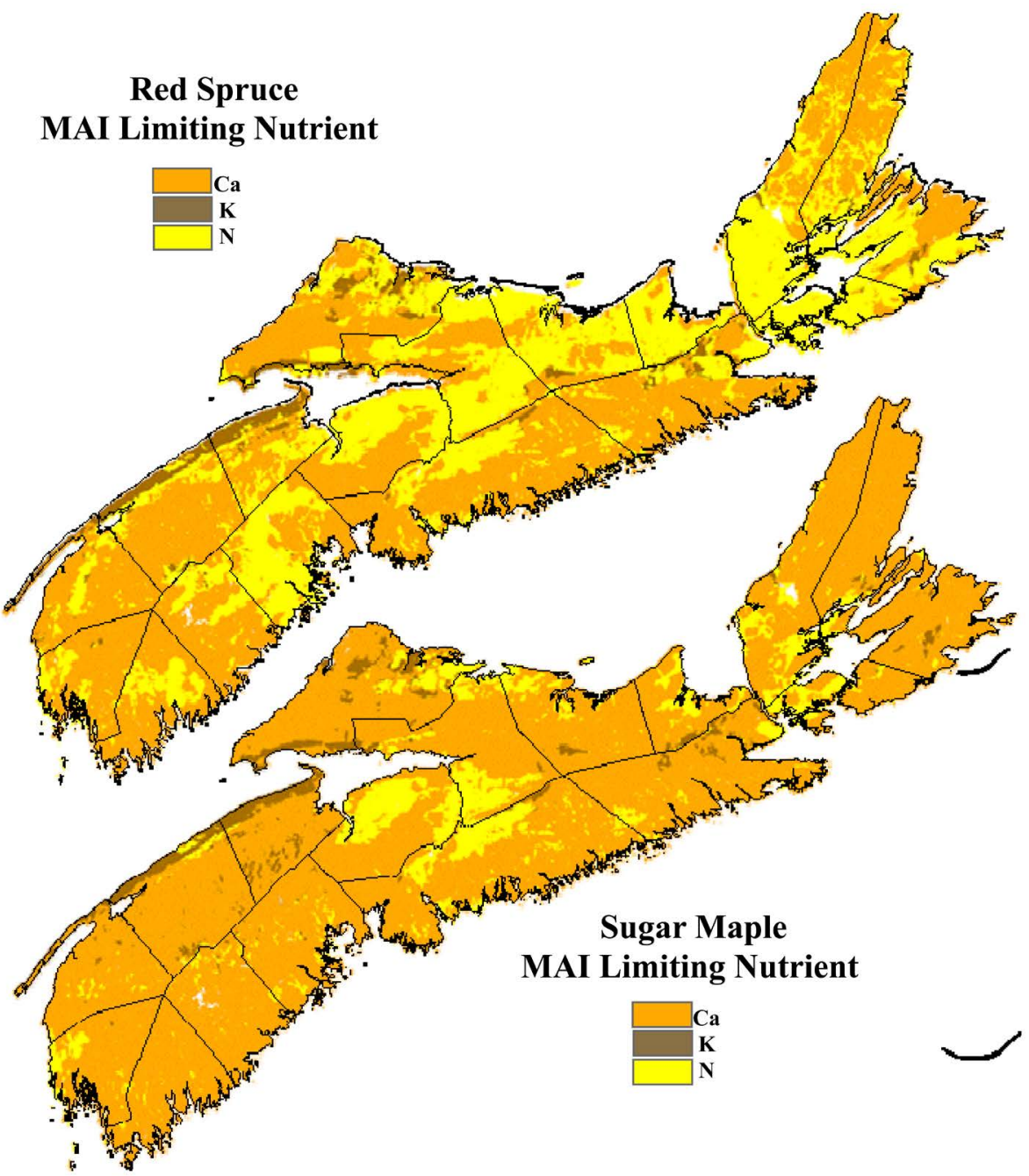

Figure 5. Map showing predicted range of MAI (growth-limiting) nutrients across Nova Scotia under $(\mathrm{A})$ uniform red spruce cover and $(\mathrm{B})$ uniform sugar maple cover. Orange $=$ calcium $(\mathrm{Ca})$, Yellow $=$ nitrogen $(\mathrm{N})$, Brown $=$ potassium $(\mathrm{K})$. 


\subsection{Plantation Survey}

A summary of measured plantation soil data is presented in Table 2. Entries are based on pooled plantation data, not individual samples, and provide insight into the similarities and differences between various soil series. For example, Halifax and Cobequid soils are derived from gravelly, sandy loam tills, but are differentiated by rocktype, and-hence—by mineralogy (MacDougall et al., 1963; Webb et al., 1991). In contrast, Queens soils are derived from non-gravelly, loam to clay loam till (Webb et al., 1991). Sampling results within these soils were variable, with $\mathrm{Mg}$ and $\mathrm{K}$ fraction data having consistently high coefficient of variation values $(21 \%-68 \%)$.

Table 2. Summary of measured plantation soil attributes.

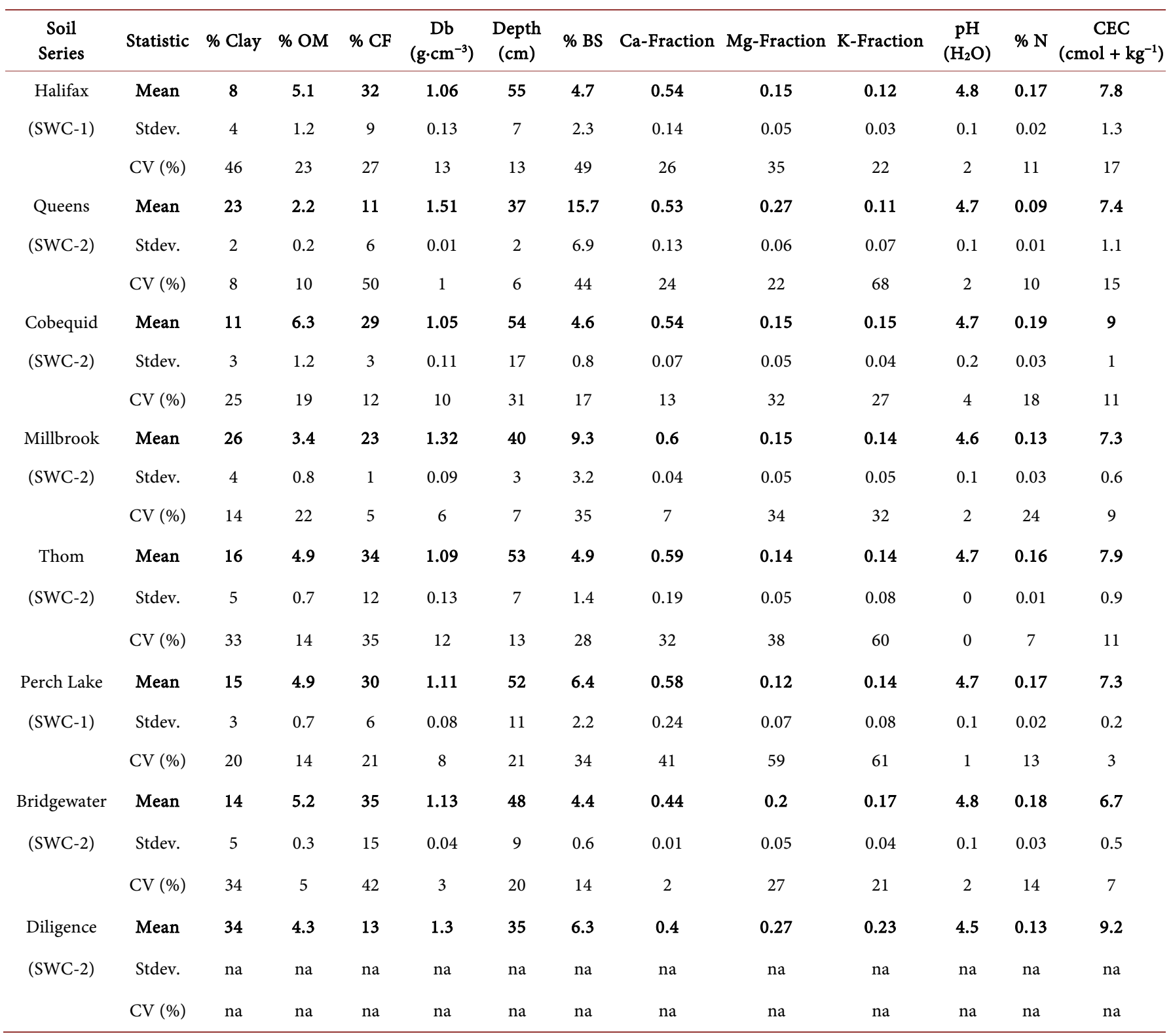

Note: ${ }^{*}$ SWC $=$ assigned Substrate Weatherability Class. 
Table 3 reports on field-determined and corresponding NBM-NS default soil data for the surveyed plantations. In all cases, field-determined values for $\% \mathrm{BS}$ and $\% \mathrm{~N}$ were lower than corresponding default data, with relative decreases ranging from $-37 \%$ to $-82 \%(\% \mathrm{BS})$ and $-19 \%$ to $-71 \%(\% \mathrm{~N})$. These differences would, at least in part, be due to the agricultural bias of early soil surveys in Nova Scotia. In addition, Nova Scotia soils were subject to acid rain caused soil acidification over several decades prior to the systematic US and Canada-wide reductions in $\mathrm{SO}_{2}$ emissions since 2000 (Whitfield et al., 2006). The low field-determined \% BS values found were similar to those reported by Whitfield et al. (2006). Field-determined CEC values were also generally lower than default values (range $-59 \%$ to $+21 \%$ ). Trends in CEC were, however, poorly correlated with changes in \% Clay and \% OM. This could, in part, be due to small sample size and appreciable scatter between field-determined and modelled CEC values (Meyer et al., 1994).

Differences between default and actual base cation $(\mathrm{Ca}, \mathrm{Mg}, \mathrm{K})$ fractions showed variable trends (range from $-58 \%$ to $+221 \%$ ), with field-determined values generally greater than default values. Simultaneous increases in $\mathrm{Ca}, \mathrm{Mg}$, and $\mathrm{K}$ fractions would be due to the assigned fractional value given to sodium (Na) in NBM-NS. The approximate weathering fraction reported by Whitfield et al. (2006) for $\mathrm{Na}$ is 0.30 . As can be

Table 3. Comparison of soil survey derived (default) and measured (plantation) soil attributes.

\begin{tabular}{|c|c|c|c|c|c|c|c|c|c|c|c|c|c|}
\hline Soil Series & Data Source & $\%$ Clay & $\% \mathrm{OM}$ & $\% \mathrm{CF}$ & $\begin{array}{c}\mathrm{Db} \\
\left(\mathrm{g} \cdot \mathrm{cm}^{-3}\right)\end{array}$ & $\begin{array}{l}\text { Depth } \\
(\mathrm{cm})\end{array}$ & $\%$ BS & Ca-Fraction & Mg-Fraction & K-Fraction & $\begin{array}{c}\mathrm{pH} \\
\left(\mathrm{H}_{2} \mathrm{O}\right)\end{array}$ & $\% \mathrm{~N}$ & $\begin{array}{c}\text { CEC } \\
\left(\mathrm{cmol}+\mathrm{kg}^{-1}\right)\end{array}$ \\
\hline \multirow{2}{*}{$\begin{array}{l}\text { Halifax } \\
\text { (SWC-1) }\end{array}$} & Default & 12 & 4.5 & 30 & 1.10 & 50 & 15.0 & 0.44 & 0.21 & 0.05 & 4.8 & 0.58 & 9.5 \\
\hline & \% Diff. & -32 & 14 & 7 & -4 & 10 & -69 & 21 & -32 & 166 & 1 & -71 & -18 \\
\hline \multirow{2}{*}{$\begin{array}{l}\text { Queens } \\
\text { (SWC-2) }\end{array}$} & Default & 25 & 1.5 & 5 & 1.50 & 40 & 25.0 & 0.44 & 0.12 & 0.14 & 4.9 & 0.27 & 10.9 \\
\hline & Plantation & 23 & 2.2 & 11 & 1.51 & 37 & 15.7 & 0.53 & 0.27 & 0.11 & 4.7 & 0.09 & 7.4 \\
\hline \multirow{2}{*}{$\begin{array}{l}\text { Cobequid } \\
(\mathrm{SWC}-2)\end{array}$} & Plantation & 11 & 6.3 & 29 & 1.05 & 54 & 4.6 & 0.54 & 0.15 & 0.15 & 4.7 & 0.19 & 9.0 \\
\hline & \% Diff. & -23 & 26 & -16 & -4 & -2 & -82 & 4 & 26 & 135 & -2 & -19 & 8 \\
\hline \multirow{2}{*}{$\begin{array}{l}\text { Millbrook } \\
(\text { SWC-2) }\end{array}$} & Default & 20 & 3.0 & 15 & 1.40 & 40 & 20.0 & 0.49 & 0.15 & 0.06 & 4.5 & 0.29 & 17.7 \\
\hline & Plantation & 26 & 3.4 & 23 & 1.32 & 40 & 9.3 & 0.60 & 0.15 & 0.14 & 4.6 & 0.13 & 7.3 \\
\hline \multirow{3}{*}{$\begin{array}{l}\text { Perch Lake } \\
(\text { SWC-1) }\end{array}$} & Default & 12 & 4.5 & 35 & 1.20 & 60 & 20.0 & 0.34 & 0.29 & 0.07 & 5.0 & 0.24 & 6.1 \\
\hline & Plantation & 15 & 4.9 & 30 & 1.11 & 52 & 6.4 & 0.58 & 0.12 & 0.14 & 4.7 & 0.17 & 7.3 \\
\hline & \% Diff. & 21 & 9 & -14 & -8 & -13 & -68 & 70 & -58 & 89 & -6 & -28 & 21 \\
\hline \multirow{3}{*}{$\begin{array}{l}\text { Bridgewater } \\
(\text { SWC-2) }\end{array}$} & Default & 15 & 5.0 & 20 & 0.90 & 55 & 15.0 & 0.50 & 0.14 & 0.06 & 5.0 & 0.25 & 10.3 \\
\hline & Plantation & 14 & 5.2 & 35 & 1.13 & 48 & 4.4 & 0.44 & 0.20 & 0.17 & 4.8 & 0.18 & 6.7 \\
\hline & \% Diff. & -7 & 5 & 73 & 25 & -12 & -70 & -13 & 46 & 193 & -4 & -29 & -35 \\
\hline \multirow{3}{*}{$\begin{array}{l}\text { Diligence } \\
(\text { SWC-2) }\end{array}$} & Literature & 30 & 2.0 & 20 & 1.50 & 35 & 15.0 & 0.43 & 0.20 & 0.07 & 4.5 & 0.28 & 21.2 \\
\hline & Plantation & 34 & 4.3 & 13 & 1.30 & 35 & 6.3 & 0.40 & 0.27 & 0.23 & 4.5 & 0.13 & 9.2 \\
\hline & $\%$ Diff. & 12 & 113 & -33 & -13 & 0 & -58 & -8 & 37 & 221 & -1 & -54 & -56 \\
\hline
\end{tabular}

Note: ${ }^{*}$ WW $=$ assigned Soil Weatherability Class. 
derived from Table 3, actual Na fractions from sampled soils ranged from 0.09 to 0.19 , i.e., in agreement with Yanni et al. (2000) who found exchangeable $\mathrm{Na}$ to be generally low in western Nova Scotia despite high rates of atmospheric Na deposition (a considerable portion of exchangeable $\mathrm{Na}$ is thought to be lost through $\mathrm{Cl}^{-}$leaching). For the remaining parameters, differences between default and actual values for $\%$ Clay $(-32 \%$ to $+36 \%), \%$ CF $(-33 \%$ to $+125 \%)$, Db $(-10 \%$ to $+25 \%)$, Depth $(-13 \%$ to $+10 \%)$, and $\mathrm{pH}(-6 \%$ to $+2 \%)$ showed no clear trends; and although field-determined $\% \mathrm{OM}$ values were higher for all soils ( $+5 \%$ to $+113 \%$ ), absolute differences only varied from $0.4 \%$ to $2.3 \%$.

In general, differences between site-specific and survey derived default values should be expected. Nevertheless, differences so accruing can affect NBM-NS output. Hence, using site-specific data is important for verifying and improving NBM-NS modelled results.

A summary of NBM-NS output using default and mean plantation soil data, together with projected plantation growth data, is presented in Table 4 (Harvesting Only losses)

Table 4. NBM-NS output for sampled plantations-harvesting only losses.

\begin{tabular}{|c|c|c|c|c|c|c|c|c|c|}
\hline Plantation & Soil Series & Species & $\begin{array}{c}\text { Projected } \\
\text { MMAI } \\
\left(\mathrm{m}^{3} \cdot \mathrm{ha}^{-1} \cdot \mathrm{yr}^{-1}\right)\end{array}$ & \multicolumn{3}{|c|}{ NBM Output-Default Data } & \multicolumn{3}{|c|}{ NBM Output-Plantation Data } \\
\hline 1 & Bridgewater & bS & 7.8 & 6.4 & -1.3 & $\mathrm{Ca} / \mathrm{K}$ & 5.0 & -2.8 & $\mathrm{Ca}$ \\
\hline 2 & Bridgewater & $\mathrm{wS}$ & 7.3 & 6.0 & -1.3 & $\mathrm{Ca} / \mathrm{K}$ & 4.6 & -2.7 & $\mathrm{Ca}$ \\
\hline 3 & Cobequid & $\mathrm{rS}$ & 7.9 & 9.2 & 1.3 & $\mathrm{~N}$ & 9.2 & 1.3 & $\mathrm{~N}$ \\
\hline 5 & Cobequid & wS & 5.6 & 6.1 & 0.5 & $\mathrm{Ca}$ & 5.5 & -0.1 & $\mathrm{Ca}$ \\
\hline 6 & Cobequid & bS & 5.7 & 6.6 & 0.9 & $\mathrm{Ca}$ & 6.0 & 0.3 & $\mathrm{Ca}$ \\
\hline 7 & Halifax & wS & 7.3 & 3.0 & -4.3 & $\mathrm{Ca} / \mathrm{K}$ & 2.7 & -4.6 & $\mathrm{Ca} / \mathrm{K}$ \\
\hline 8 & Halifax & wS & 7.3 & 3.0 & -4.3 & $\mathrm{Ca} / \mathrm{K}$ & 2.6 & -4.7 & $\mathrm{Ca} / \mathrm{K}$ \\
\hline 9 & Halifax & bS & 7.8 & 3.2 & -4.6 & $\mathrm{Ca} / \mathrm{K}$ & 2.8 & -4.9 & $\mathrm{Ca} / \mathrm{K}$ \\
\hline 13 & Millbrook & bS & 7.8 & 8.2 & 0.4 & $\mathrm{~N}$ & 8.2 & 0.4 & $\mathrm{~N}$ \\
\hline 14 & Millbrook & $\mathrm{wS}$ & 7.3 & 7.7 & 0.3 & $\mathrm{~N}$ & 7.7 & 0.3 & $\mathrm{~N}$ \\
\hline 15 & Thom & wS & 5.6 & 7.8 & 2.2 & $\mathrm{~N}$ & 6.9 & 1.4 & $\mathrm{Ca}$ \\
\hline 16 & Millbrook & wS & 7.3 & 7.7 & 0.4 & $\mathrm{~N}$ & 7.7 & 0.4 & $\mathrm{~N}$ \\
\hline 17 & Perch Lake & NS & 8.8 & 2.8 & -5.9 & $\mathrm{Ca} / \mathrm{N} / \mathrm{K}$ & 4.6 & -4.2 & $\mathrm{Ca} / \mathrm{N}$ \\
\hline 18 & Perch Lake & wS & 7.1 & 2.9 & -4.3 & $\mathrm{Ca} / \mathrm{K}$ & 4.6 & -2.5 & $\mathrm{Ca}$ \\
\hline 19 & Perch Lake & wS & 5.6 & 2.9 & -2.7 & $\mathrm{Ca}$ & 4.6 & -1.0 & $\mathrm{~N} / \mathrm{Ca}$ \\
\hline 20 & Queens & NS & 10.4 & 7.7 & -2.7 & $\mathrm{~N} / \mathrm{Ca}$ & 7.7 & -2.7 & $\mathrm{~N}$ \\
\hline 21 & Queens & wS & 7.3 & 7.8 & 0.5 & $\mathrm{~N}$ & 7.8 & 0.5 & $\mathrm{~N}$ \\
\hline 22 & Queens & $\mathrm{wS}$ & 7.1 & 8.1 & 0.9 & $\mathrm{~N}$ & 8.1 & 0.9 & $\mathrm{~N}$ \\
\hline
\end{tabular}

Note: ${ }^{\star} \mathrm{bS}=$ black spruce, $\mathrm{wS}=$ white spruce, $\mathrm{rS}=$ red spruce, $\mathrm{NS}=$ Norway Spruce. 
and Table 5 (Harvesting + Depletion). All harvesting assumed 100\% removal of stemwood and bark with $0 \%$ removal of branches and foliage (i.e., a very efficient conventional stem-only harvesting processed at the stump). A summary of plantation regime sustainability by model configuration is given in Table 6 .

The MAI Diff. entries in Table 4 and Table 5 were used to compare model calculated SusMAI with merchantable mean annual increment (MMAI) by projected management regime. Negative MAI Diff. values indicate that the projected (or desired) yields over the long term (several rotations with same yield expectations) cannot be sustained

Table 5. NBM-NS output for sampled plantations-Harvesting + Depletion.

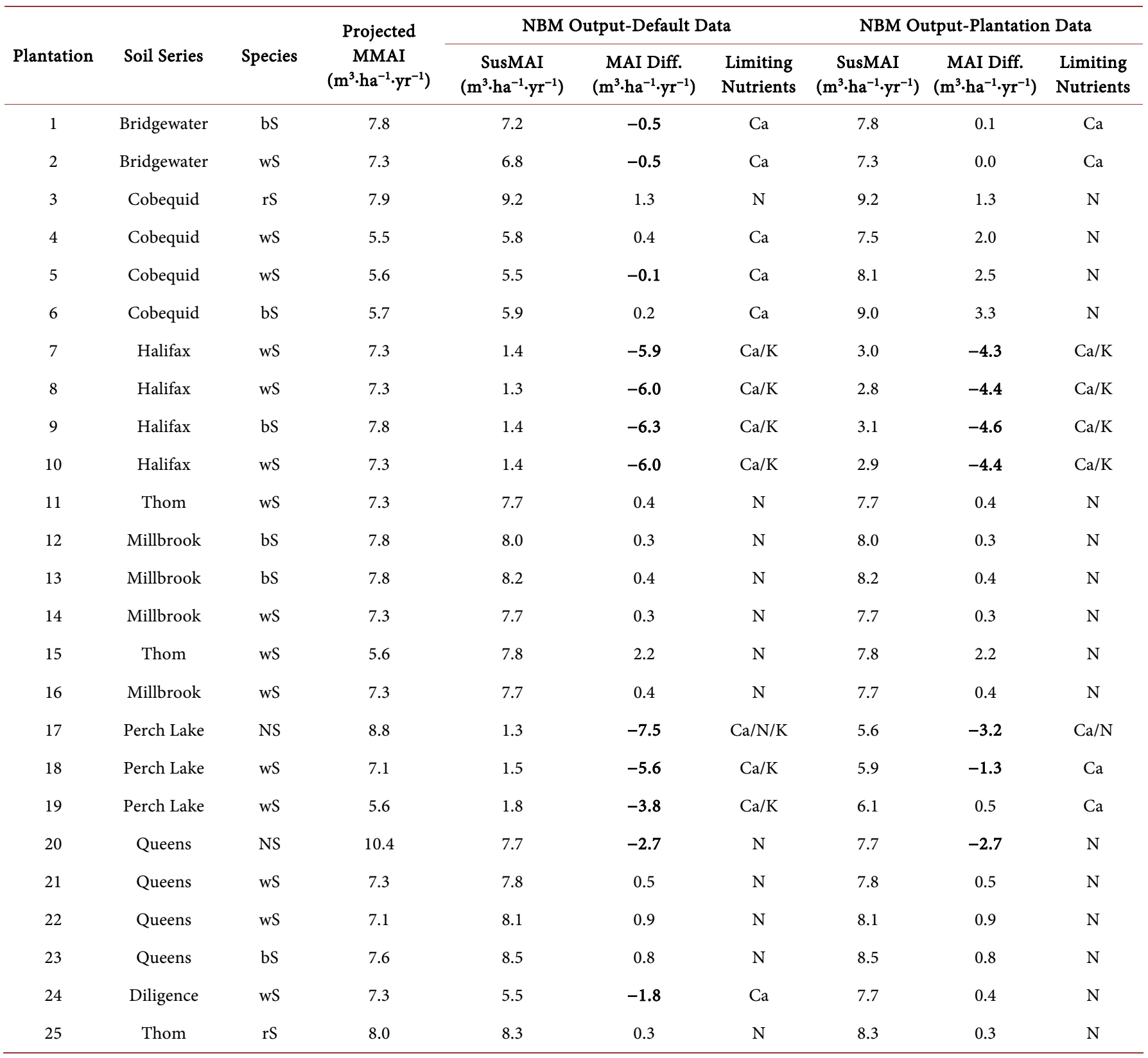

Note: ${ }^{b} \mathrm{bS}=$ black spruce, $\mathrm{wS}=$ white spruce, $\mathrm{rS}=$ red spruce, $\mathrm{NS}=$ Norway Spruce. 
Table 6. Number of plantations with predicted SusMAI less than projected MMAI by model configuration.

\begin{tabular}{cc}
\hline NBM-NS Configuration & Plantations with Predicted SusMAI < Projected MMAI \\
\hline Default soil data with Harvest Only losses & $11(44 \%)$ \\
Plantation soil data with Harvest Only losses & $13(52 \%)$ \\
Default soil data with Harvest + Depletion & $12(48 \%)$ \\
Plantation soil data with Harvest + Depletion & $7(28 \%)$ \\
\hline
\end{tabular}

without increased nutrient inputs or reduced harvest expectations. When MAI Diff. is positive, projected yields are predicted to be nutrient sustainable over the long term under current atmospheric deposition conditions. In both cases, growth-limiting nutrients, i.e., those that constrain SusMAI, are listed in order of importance. Several points arise from Tables 4-6:

- Based on comparisons with NBM-NS output, approximately $1 / 4$ to $1 / 2$ of the assessed plantation sites have non-sustainable MMAI yield expectations.

- Best MAI-sustainability outcomes are obtained by enabling NBM-NS depletion functions and using site-specific soil data. This occurs when the $K_{\text {exch }} A C_{l e} / B C_{l e}$ specified $B S_{f}$ value is larger than the field-determined BS value. In this case, base cation depletion calculations generate a positive result whereby some $B S_{f}$ determined leaching of base cations can be taken up by vegetation while still maintaining current BS value. However, soil quality, tree health, and rooting vigour must be considered as well (see discussion below).

- Plantations with non-sustainable MMAI values are mainly associated with low soil weathering classes (especially Class 1) and/or tree species with high nutrient demands (e.g., Norway spruce).

- $\mathrm{Ca}$ and $\mathrm{N}$ are the most common growth-limiting nutrients.

To better understand how site-specific soil data and model configuration influences NBM-NS output, a sample plantation with a range of output is examined in further detail (Table 7). Entries in this table refer to default and site-specific soil data for Plantation 19 (white spruce underlain by Perch Lake soil), and to the changes in predicted SusMAI by adjusting each individual soil parameter for the Harvest Only and Harvest + Depletion scenarios. As shown, the largest single impact on SusMAI under the Harvest Only scenario (+53\%) comes from the $71 \%$ increase in Ca fraction above its default value (Ca being the growth-limiting nutrient at this site, Table 4 ). The $25 \%$ increase in clay also has a positive impact on SusMAI $(+17 \%)$, but this would-in part-be compensated by default differences in soil depth and density. Overall, using plantation versus default data as NBM-NS input leads to an estimated 60\% SusMAI increase (to 4.6 $\mathrm{m}^{3} \cdot \mathrm{ha}^{-1} \cdot \mathrm{yr}^{-1}$ ). This increase, however, is still not sufficient to match the projected (or desired) MMAI of $5.6 \mathrm{~m}^{3} \cdot \mathrm{ha}^{-1} \cdot \mathrm{yr}^{-1}$ (Table 4$)$.

Under the Harvest + Depletion scenario, SusMAI may be greater or smaller than what is estimated by harvest deficiency alone, with Table 7 suggesting an increase in SusMAI towards $6.1 \mathrm{~m}^{3} \cdot \mathrm{ha}^{-1} \cdot \mathrm{yr}^{-1}$. Highest SusMAI expectations via NBM-NS are 
Table 7. NBM-NS output for Plantation 19 showing changes in SusMAI for each change in soil parameter. Predicted SusMAI with all parameters adjusted is also listed for reference purposes.

\begin{tabular}{|c|c|c|c|c|c|c|c|c|c|}
\hline Parameter & \multicolumn{3}{|c|}{ Soil Data } & \multicolumn{3}{|c|}{ SusMAI $\left(\mathrm{m}^{3} \cdot \mathrm{ha}^{-1} \cdot \mathrm{yr}^{-1}\right)$ Harvest Only } & \multicolumn{3}{|c|}{ SusMAI $\left(\mathrm{m}^{3} \cdot \mathrm{ha}^{-1} \cdot \mathrm{yr}^{-1}\right)$ Harvest + Depletion } \\
\hline Depth $(\mathrm{cm})$ & 60 & 52 & -13 & 2.9 & 2.6 & -10 & 1.8 & 1.2 & -33 \\
\hline$\%$ Clay & 12 & 15 & 25 & 2.9 & 3.4 & 17 & 1.8 & 2.8 & 54 \\
\hline$\% \mathrm{CF}$ & 35 & 30 & -14 & 2.9 & 3 & 6 & 1.8 & 2.1 & 19 \\
\hline$\% \mathrm{OM}$ & 4.5 & 4.9 & 9 & 2.9 & 2.9 & 0 & 1.8 & 1.8 & -1 \\
\hline$\% \mathrm{BS}$ & 20 & 6.4 & -68 & 2.9 & 2.9 & 0 & 1.8 & 3.6 & 103 \\
\hline Ca Fraction & 0.34 & 0.58 & 71 & 2.9 & 4.4 & 53 & 1.8 & 2.5 & 42 \\
\hline Mg Fraction & 0.29 & 0.12 & -58 & 2.9 & 2.9 & 0 & 1.8 & 1.8 & 0 \\
\hline
\end{tabular}

obtained when all available base cations obtained through weathering and atmospheric deposition are taken up by vegetation. This, however, would allow for no replenishment of depleted base cations on CES, and $B S_{f}$ could theoretically drop to zero while tree growth and fine root vigour would be substantially impaired by way of increased $\mathrm{Al}^{3+}$ concentrations (Driscoll et al., 2001; Duarte et al., 2013). Therefore, when \% BS levels are low, it is even more important to monitor base cation removals from harvesting so as not to exacerbate the problem by way of increased MMAI expectations. Cronan and Grigal (1995) suggest 15\% BS as a threshold below which "aluminum stress" occurs in forest soils, and Driscoll et al. (2001) suggest 20\% BS as a general value for assessing soil recovery from already incurred acid deposition impacts. Any \% BS value can be directly assigned within NBM-NS, so sustainable harvest rates can be based on these threshold values rather than using current or default values. In the case of Plantation 19, assigning BS values of $15 \%$ and $20 \%$ resulted in estimated SusMAI values of $3.7 \mathrm{~m}^{3} \cdot \mathrm{ha}^{-1} \cdot \mathrm{yr}^{-1}$ and $2.9 \mathrm{~m}^{3} \cdot \mathrm{ha}^{-1} \cdot \mathrm{yr}^{-1}$ respectively (using site-specific data for other variables). Both of these values are below the projected (or desired) MMAI of 5.6 $\mathrm{m}^{3} \cdot \mathrm{ha}^{-1} \cdot \mathrm{yr}^{-1}$ for this site, as well as the SusMAI value of $4.6 \mathrm{~m}^{3} \cdot \mathrm{ha}^{-1} \cdot \mathrm{yr}^{-1}$, obtained when considering harvesting deficiencies alone.

\subsection{NBM-NS Assumptions and Limitations}

Based on its design, NBM-NS can only evaluate a single site condition and harvest scenario combination over time. As such, this model does not accommodate changing cover types or multiple interventions over time within a single model run. Other site productivity components such as potential ground disturbance and climate change impacts also need to be considered. In addition, NBM-NS does not account for N-fixation, harvest-pulse leaching, and low-area seepage effects on nutrient budgets. While longterm nutrient sustainability across forest sites can be addressed, current input data may 
require site-specific corrections. For example, Ca has long been considered a nutrient of concern in eastern North America (Freedman et al., 1986; Federer et al., 1989; Adams et al., 2000; Huntington, 2005; Campbell et al., 2009), and this is supported by NBM-NS output which identifies $\mathrm{Ca}$ as the most frequent growth limiting nutrient in addition to $\mathrm{N}$. As suggested above, loss of $\mathrm{Ca}$ (and other base cations) from decades of acid deposition has probably contributed to the low $\%$ BS values found in plantation soils compared to values derived from historic soil surveys.

With Ca recognized as a common limiting nutrient in eastern forest soils (Huntington, 2005), it is important to accurately model soil weathering rates. Whitfield et al. (2006) showed weathering rates estimated via the Clay Content method to be comparable to those obtained using more elaborate methods ( $\mathrm{Zr}$ Depletion and PROFILE model) for five Nova scotia sites with very low clay contents $\left(30-130 \mathrm{eq} \cdot \mathrm{ha}^{-1} \cdot \mathrm{yr}^{-1}\right)$. These values are generally lower than those generated by NBM-NS for this study (Table 8), but plantation soils had higher clay contents and/or a higher substrate weatherability class than the acid soils assessed by Whitfield et al. (2006). The range in estimated weathering input shown in Table 8 (196 - $\left.967 \mathrm{eq} \cdot \mathrm{ha}^{-1} \cdot \mathrm{yr}^{-1}\right)$ is in keeping with values compiled by Ouimet and Duchesne (2005) for other northeastern sites. This confluence of results increases overall confidence over and above any single estimate (Futter et al., 2012), and justifies the use of the more easily applied Clay Content method within NBM-NS.

The main problem in using the Clay Content method comes from appropriately assigning soil/substrate weathering classes. For the NBM-NS case study, Halifax, Perch Lake, Queens, Millbrook, Bridgewater, and Diligence soils were easily assigned a weathering class, but Cobequid and Thom soils required Class 1 to Class 2 intermediate assignments. In future, weathering rates could also be impacted by climate-induced changes in soil temperature and moisture regimes, with longer growing seasons potentially enhancing not only soil weathering, but also base cation uptake during the growing season and base cation leaching outside the growing season (Oja \& Arp 1996; Campbell et al., 2009; Huntington et al., 2009).

Table 8. NBM-NS calculated soil weathering inputs based on the Clay Content method using measured case study soil data.

\begin{tabular}{|c|c|c|c|c|c|}
\hline Soil Series & Weatherability Class & $\begin{array}{c}\text { Calculated Total Base } \\
\text { Cation Input }\left(\mathrm{eq} \cdot \mathrm{ha}^{-1} \cdot \mathrm{yr}^{-1}\right)\end{array}$ & $\begin{array}{l}\text { Estimated Ca Input } \\
\quad\left(\mathrm{eq} \cdot \mathrm{ha}^{-1} \cdot \mathrm{yr}^{-1}\right)\end{array}$ & $\begin{array}{l}\text { Estimated } \mathrm{Mg} \text { Input } \\
\quad\left(\mathrm{eq} \cdot \mathrm{ha}^{-1} \cdot \mathrm{yr}^{-1}\right)\end{array}$ & $\begin{array}{l}\text { Estimated K Input } \\
\left(\mathrm{eq} \cdot \mathrm{ha}^{-1} \cdot \mathrm{yr}^{-1}\right)\end{array}$ \\
\hline Halifax & 1 & 196 & 105 & 28 & 23 \\
\hline Queens & 2 & 967 & 515 & 256 & 103 \\
\hline Cobequid & 2 & 480 & 259 & 73 & 71 \\
\hline Thom & 2 & 568 & 336 & 78 & 80 \\
\hline Perch Lake & 1 & 359 & 207 & 43 & 50 \\
\hline Bridgewater & 2 & 494 & 216 & 100 & 85 \\
\hline Diligence & 2 & 961 & 384 & 258 & 219 \\
\hline
\end{tabular}


NBM-NS can be used as both a landscape planning tool (using default data) and a stand-level planning tool (using site-specific soil data). This study suggests, however, that care must be taken when using old soil survey data to initialize nutrient budget models such as NBM-NS. Nova Scotia is one of the few provinces in Canada that has essentially all of its area covered by soil surveys, but the accumulated database may not be reflective of current forest soil conditions, as apparent from the case study change towards lower \% BS values. The model is, however, easily updated as new soil data become available.

Atmospheric deposition data used in NBM-NS can also be updated when available. For this article, we used the 2002 atmospheric deposition maps for S, N, Ca, Mg, and $\mathrm{K}$ from Environment Canada. However, according to Canada's NATChem database for wet atmospheric deposition, the Canadian Air and Precipitation Monitoring Network (CAPMoN) stations at Kejimkujik National Park (Latitude 44:26:0, Longitude 65:12:21 and Jackson (Acadia: Latitude 45:35:35, Longitude 63:50:30) suggest the following volume-weighted concentration trends:

- a steady decline for $\mathrm{SO}_{4}$-S deposition since 1985 with

$\mathrm{SO}_{4}\left(\mathrm{mg} \cdot \mathrm{L}^{-1}\right)=1.166-0.024$ (years since 1985$), \mathrm{R}^{2}=0.73$;

- a more scattered decline pattern for $\mathrm{NO}_{3}-\mathrm{N}$ deposition, with

$\mathrm{NO}_{3}\left(\mathrm{mg} \cdot \mathrm{L}^{-1}\right)=0.808-0.015$ (years since 1985), $\mathrm{R}^{2}=0.54$

- $\mathrm{NH}_{4}\left(\mathrm{mg} \cdot \mathrm{L}^{-1}\right)=0.102-0.000$ (years since 1985$) \mathrm{R}^{2}=0.02$, i.e., no change;

- $\mathrm{Ca}+\mathrm{Mg}+\mathrm{K}\left(\mu \mathrm{eq} \cdot \mathrm{L}^{-1}\right)=25.83+0.11$ (years since 1985) $\mathrm{R}^{2}=0.11$, i.e., slight increase.

These trends imply a general reduction in atmospheric acid deposition, which-in turn-would reduce soil acidity, increase soil base saturation, but lower the amount of available soil $\mathrm{N}$. As a result, in future, $\mathrm{N}$ rather than $\mathrm{Ca}$ and $\mathrm{K}$ could become more growth limiting on some sites.

\subsection{Management Implications}

Although differences in site quality and species suitability are well understood by forest managers, it is often assumed that increased yields predicted through intensive management are sustainable on any given site. This perception is likely due to (i) the long time frames associated with forest management, including plantation management, (ii) the relatively short history of intensive forest management in Canada, (iii) gradual rather than abrupt changes in growth-limiting factors, and (iv) the lack of effective tools to evaluate forest nutrient sustainability.

Although not perfect, models like NBM-NS (combined with necessary GIS data) allow forest managers to better evaluate planned management regimes with respect to regional and local nutrient inputs, and to make adjustments to accommodate predictable nutrient deficits. For example, species selection, percent removals, and rotation lengths can all be adjusted to varying degrees to reduce the amount and timing of nutrient outputs and related shortfalls. In some cases, as in intensive plantation management, soil amendments could also be applied to offset nutrient losses from harvesting and continued soil leaching. 
Although recent NATChem data shows that acid deposition across Nova Scotia has decreased, the problem and legacy of base cation depletion is still a concern in northeastern forests (e.g., Driscoll et al., 2001; Watmough, 2005; Johnson et al., 2008; Warby et al., 2009). Also, while decreasing $\mathrm{N}$ inputs can potentially reduce cation leaching where $\mathrm{N}$ is not limiting, it also means less available $\mathrm{N}$ for sites that are $\mathrm{N}$-limited, thereby potentially reducing potential productivity on these sites.

\section{Conclusion}

This paper describes a geospatial, GIS-linked nutrient budget model (NBM-NS) that can be used to:

- predict long-term sustainability of forest harvesting regimes in relation to primary nutrient input and output estimates;

- estimate sustainable mean annual increment (SusMAI) values for individual stands or sites by determining limiting nutrient levels; and

- develop nutrient-based site quality assessments based on soil/substrate characteristics and atmospheric deposition data.

Although specifically designed for use in Nova Scotia, a similar model could be developed for any region assuming necessary data are available. When used to assess the sustainability of 25 sample spruce plantations, NBM-NS predicted nutrient declines for several sites, suggesting the need to adjust long-term yield expectations and/or management regimes for these site types.

It is recommended that nutrient budget assessments (such as provided by NBM-NS) become an integral component of sustainable forest management planning, especially when considering intensive management regimes or biomass harvesting for energy. Nutrient assessments are even more important in areas that have been impacted by long-term acid deposition since harvest removals can exacerbate declines in base cation levels (especially $\mathrm{Ca}$ ) in affected soils. In doing so, it is important to ensure that model input is as accurate as possible, since budget estimates are directly related to soil/site conditions.

\section{Acknowledgements}

The authors wish to thank the Canadian National Atmospheric Chemistry (NATChem) Database and its data contributing agencies/organizations for providing mean wet deposition grid and station data, with special thanks to Robert Vet and Michael Moran of Environment Canada for their Eastern Canada extension. NBM-NS development was funded by the Nova Scotia Department of Natural Resources with conceptual, technical, and further financial support realized at the Forest Watershed Research Centre at the University of New Brunswick. Plantation soil assessment was funded by a National Sciences and Engineering Research Council (NSERC) Engage grant in collaboration with Dalhousie University Agricultural Campus and Northern Pulp Nova Scotia Corporation. 


\section{References}

AAFC (Agriculture and Agri-Foods Canada) (2009). Daily $10 \mathrm{~km}$ Grid Climate Dataset for Canada, 2004-2008 (ANUSPLIN Raster Grid). Government of Canada.

Adams, M. B., Burger, J. A., Jenkins, A. B., \& Zelazny, L. (2000). Impact of Harvesting and Atmospheric Pollution on Nutrient Depletion of Eastern US Hardwood Forests. Forest Ecology and Management, 138, 301-319. http://dx.doi.org/10.1016/S0378-1127(00)00421-7

Ågren, G. I. (1985). Limits to Plant Production. Journal of Theoretical Biology, 113, 89-92. http://dx.doi.org/10.1016/S0022-5193(85)80078-3

Arp, P. A., Leger, W., Moayeri, M. H., \& Hurley, J. E. (2001). Methods for Mapping Forest Sensitivity to Acid Deposition for Northeastern North America. Ecosystem Health, 7, 35-47. http://dx.doi.org/10.1046/j.1526-0992.2001.710035.x

Arthur, M. A., Siccama, T. G., \& Yanai, R. D. (1999). Calcium and Magnesium in Wood of Northern Hardwood Forest Species: Relations to Site Characteristics. Canadian Journal of Forest Research, 29, 339-346. http://dx.doi.org/10.1139/x98-210

Campbell, J. L., Rustad, L. E., Boyer, E. W., Christopher, S. F., Driscoll, C. T., Fernandez, I. J., Groffman, P. M., Houle, D., Kiekbusch, J., Magill, A. H., Mitchell, M. J., \& Ollinger, S. V. (2009). Consequences of Climate Change for Biogeochemical Cycling in Forests of Northeastern North America. Canadian Journal of Forest Research, 39, 264-284.

http://dx.doi.org/10.1139/X08-104

Cronan, C. S., \& Grigal, D. F. (1995). Use of Calcium Aluminium Ratios as Indicators of Stress in Forest Ecosystems. Journal of Environmental Quality, 24, 209-226. http://dx.doi.org/10.2134/jeq1995.00472425002400020002x

de Vries, W., Posch, M., Oja, T., van Oene, H., Kros, J., \& Arp, P. A. (1995). Modelling Critical Loads for the Solling Spruce Sit. Ecological Modelling, 83, 283-293.

de Vries, W. (1991). Methodologies for the Assessment and Mapping of Critical Loads and of the Impact of Abatement Strategies on Forest Soils. Report 46, Wageningen: The Winand Staring Centre for Integrated Land, Soil, and Water Research.

de Vries, W., Posch, M., Reinds, G. J., \& Kamari, J. (1992). Critical Loads and Their Exceedance on Forest Soils in Europe. Report 58, Wageningen: The Winand Staring Centre for Integrated Land, Soil, and Water Research.

Driscoll, C. T., Lawrence, G. B., Bulger, A. J., Butler, T. J., Cronan, C. S., Eagar, C., Lambert, K. F., Likens, G. E., Stoddard, J. L., \& Weathers, K. C. (2001). Acid Rain Revisited: Advances in Scientific Understanding Since the Passage of the 1970 and 1990 Clean Air Act Amendments. Vol. 1, No. 1, Hubbard Brook Research Foundation, Science Links Publication.

Duarte, N., Pardo, L. H., \& Robin-Abbott, M. J. (2013). Susceptibility of Forests in the Northeastern USA to Nitrogen and Sulfur Deposition: Critical Load Exceedance and Forest Health. Water, Air, \& Soil Pollution, 224, 1355-1375. http://dx.doi.org/10.1007/s11270-012-1355-6

Federer, C., Hornbeck, J., Tritton, L., Martin, C., Pierce, R., \& Smith, C. (1989). Long-Term Depletion of Calcium and Other Nutrients in Eastern US Forests. Environmental Management, 13, 593-601. http://dx.doi.org/10.1007/BF01874965

Freedman, B., Duinker, P. N., \& Morash, R. (1986). Biomass and Nutrients in Nova Scotia Forests, and Implications of Intensive Harvesting for Future Site Productivity. Forest Ecology and Management, 15, 103-127. http://dx.doi.org/10.1016/0378-1127(86)90140-4

Futter, M. N., Klaminder, J., Lucas, R. W., Laudon, H., \& Kohler, S. J. (2012). Uncertainty in Silicate Mineral Weathering Rate Estimates: Source Partitioning and Policy Implications. Environmental Research Letters, 7, Article ID: 024025. 
Gonzalez, J. S. (1990). Wood Density of Canadian Tree Species. Information Report NOR-X-315, Edmonton, Alberta: Forestry Canada, Northwest Region, Northern Forestry Centre.

Huntington, T. G. (2005). Assessment of Calcium Status in Maine Forests: Review and Future Projection. Canadian Journal of Forest Research, 35, 1109-1121.

http://dx.doi.org/10.1139/x05-034

Huntington, T. G., Richardson, A. D., McGuire, K. J., \& Hayhoe, K. (2009). Climate and Hydrologic Changes in the Northeastern United States: Recent Trends and Implications for Forested and Aquatic Ecosystems. Canadian Journal of Forest Research, 39, 199-212.

http://dx.doi.org/10.1139/X08-116

Johnson, A. H., Moyer, A., Bedison, J. E., Richter, S. L., \& Willig, S. A. (2008). Seven Decades of Calcium Depletion in Organic Horizons of Adirondack Forest Soils. Soil Science Society of America Journal, 72, 1824-1830. http://dx.doi.org/10.2136/sssaj2006.0407

Lambert, M.-C., Ung, C.-H., \& Raulier, F. (2005). Canadian National Tree Aboveground Biomass Equations. Canadian Journal of Forest Research, 35, 1996-2018. http://dx.doi.org/10.1139/x05-112

MacDougall, J. I., Cann, D. B., \& Hilchey, J. D. (1963). Soil Survey of Halifax County, Nova Scotia. Nova Scotia Soil Survey Report No. 13, Canadian Department of Agriculture.

McGrath, T. (2011). Land Capability and Site Index Curves for Nova Scotia Hardwoods (8 p). Report 2011-3 (FRR No. 92), Nova Scotia Department of Natural Resources.

Meyer, W. L., Marsh, M., \& Arp, P. A. (1994). Cation Exchange Capacities of Upland Soils in Eastern Canada. Canadian Journal of Soil Science, 74, 393-408.

http://dx.doi.org/10.4141/cjss94-053

Moayeri, M. (2000). Mass Balance Related Sustainability of Forest Biomass Production: Concepts and Applications. PhD Thesis, Fredericton: University of New Brunswick.

Nasr, M., Castonguay, M., Ogilvie, J., Raymond, B. A., \& Arp, P. A. (2010). Modelling and Mapping Critical Loads and Exceedances for the Georgia Basin, British Columbia, Using a Zero Base-Cation Depletion Criterion. Journal of Limnology, 69, 181-192.

http://dx.doi.org/10.4081/jlimnol.2010.s1.181

NEG-ECP (2001). Critical Load of Sulphur and Nitrogen Assessment and Mapping Protocol for Upland Forests. Halifax, Nova Scotia: New England Governors and Eastern Canadian Premiers Environmental Task Group, Acid Rain Action Plan.

Neily, P., Keys, K., Quigley, E., Basquill, S., \& Stewart, B. (2013). Forest Ecosystem Classification for Nova Scotia (2010). Report FOR 2013-1, Nova Scotia Department of Natural Resources.

Noseworthy, J. (2011). A Mass Balance, Biogeochemical Framework for Assessing Forest Biomass Harvest Sustainability. MSc Thesis, Fredericton: University of New Brunswick.

NSDLF (Nova Scotia Department of Lands and Forests) (1990). Revised Normal Yield Tables for Nova Scotia Softwoods (45 p). FRR No. 22, Nova Scotia Department of Lands and Forests.

Oja, T., \& Arp, P. A. (1996). Nutrient Cycling and Biomass Growth at a North American Hardwood Site in Relation to Climate Change: ForSVA Assessments. Climatic Change, 34, 239-251. http://dx.doi.org/10.1007/BF00224635

Ouimet, R., \& Duchesne, L. (2005). Base Cation Mineral Weathering and Total Release Rates from Soils in Three Calibrated Forest Watersheds on the Canadian Boreal Shield. Canadian Journal of Soil Science, 85, 245-260. http://dx.doi.org/10.4141/S04-061

Ouimet, R., Duchesne, L., Houle, D., \& Arp, P. A. (2001). Critical Loads and Exceedances of Acid Deposition and Associated Forest Growth in the Northern Hardwood and Boreal Coniferous Forests in Quebec, Canada. Water, Air and Soil Pollution: Focus, 1, 119-134.

http://dx.doi.org/10.1023/A:1011544325004 
Ouimet, R., Arp, P. A., Watmough, S. A., Aherne, J., \& DeMerchant, I. (2006). Determination and Mapping Critical Loads of Acidity and Exceedances for Upland Forest Soils in Eastern Canada. Water, Air, and Soil Pollution, 172, 57-66.

http://dx.doi.org/10.1007/s11270-005-9050-5

Pardo, L. H., Robin-Abbott, M., Duarte, N., \& Miller, E. K. (2005). Tree Chemistry Database (Version 1.0). General Technical Report NE-324, Northeastern Research Station, USDA Forest Service.

Ranger, J., \& Turpault, M.-P. (1999). Input-Output Nutrient Budgets as a Diagnostic Tool for Sustainable Forest Management. Forest Ecology and Management, 122, 139-154. http://dx.doi.org/10.1016/S0378-1127(99)00038-9

Ro, C. U., \& Vet, R. J. (2002). Analyzed Data Fields from the National Atmospheric Chemistry Database (NATChem) and Analysis Facility. Toronto, Ontario: Air Quality Research Branch, Meteorological Service of Canada, Environment Canada.

Sverdrup, H., \& Rosen, K. (1998). Long-Term Base Cation Mass Balances for Swedish Forests and the Concept of Sustainability. Forest Ecology and Management, 110, 221-236.

http://dx.doi.org/10.1016/S0378-1127(98)00283-7

Sverdrup, H., deVries, W., \& Henriksen, A. (1990). Mapping Critical Loads: A Guidance to the criteria, Calculations, Data Collection, and Mapping of Critical Loads. Report NORD 98, Copenhagen, Denmark: Nordic Council of Ministers.

Tew, D. T., Morris, L. A., Allen, H. L., \& Wells, C. G. (1986). Estimates of Nutrient Removal, Displacement, and Loss Resulting from Harvest and Site Preparation of a Pinus taeda Plantation in the Piedmont of North Carolina. Forest Ecology and Management, 15, 257-267. http://dx.doi.org/10.1016/0378-1127(86)90163-5

Thiffault, E., Hannam, K. D., Paré, D., Titus, B. D., Hazlett, P. W., Maynard, D. G., \& Brais, S. (2011). Effects of Forest Biomass Harvesting on Soil Productivity in Boreal and Temperate Forests-A Review. Environmental Reviews, 19, 278-309. http://dx.doi.org/10.1139/a11-009

van der Ploeg, R. R., Böhm, W., \& Kirkham, M. B. (1999). On the Origin of the Theory of Mineral Nutrition of Plants and the Law of the Minimum. Soil Science Society of America Journal, 63, 1055-1062. http://dx.doi.org/10.2136/sssaj1999.6351055x

Warby, R. A. F., Johnson, C. E., \& Driscoll, C. T. (2009). Continuing Acidification of Organic Soils across the Northeastern USA: 1984-2001. Soil Science Society of America Journal, 73, 274-284. http://dx.doi.org/10.2136/sssaj2007.0016

Watmough, S. (2005). Base Cation Budgets for Eastern Canadian Forests. Chapter 5.7.1. In Canadian Acid Deposition Science Assessment 2004. Downsview, Ontario: Meteorological Service of Canada, Environment Canada.

Webb, K. T., Thompson, R. L., Beke, G. J., \& Nowland, J. L. (1991). Soils of Colchester County, Nova Scotia. Nova Scotia Soil Survey Report No. 19, Research Branch, Agriculture Canada.

Whitfield, C. J., Watmough, S. A., Aherne, J., \& Dillon, P. J. (2006). A Comparison of Weathering Rates for Acid-Sensitive Catchments in Nova Scotia, Canada and Their Impact on Critical Load Calculations. Geoderma, 136, 899-911. http://dx.doi.org/10.1016/j.geoderma.2006.06.004

Yanni, S. (1996). Hydrogeochemical Assessment of Water in Forested Watersheds at Kejimkujik National Park: Discharge Rates, Chemical Composition, and Ion Fluxes. MSc Thesis, Fredericton: University of New Brunswick.

Yanni, S., Keys, K., Clair, T. A., \& Arp, P. A. (2000). Fog and Acidification Impacts on Ion Budgets of Basins in Nova Scotia, Canada. Journal of the American Water Resources Association, 36, 619-631. http://dx.doi.org/10.1111/j.1752-1688.2000.tb04292.x 


\section{Appendix 1}

\section{Chronological order of Nova Scotia Soil Survey Reports.}

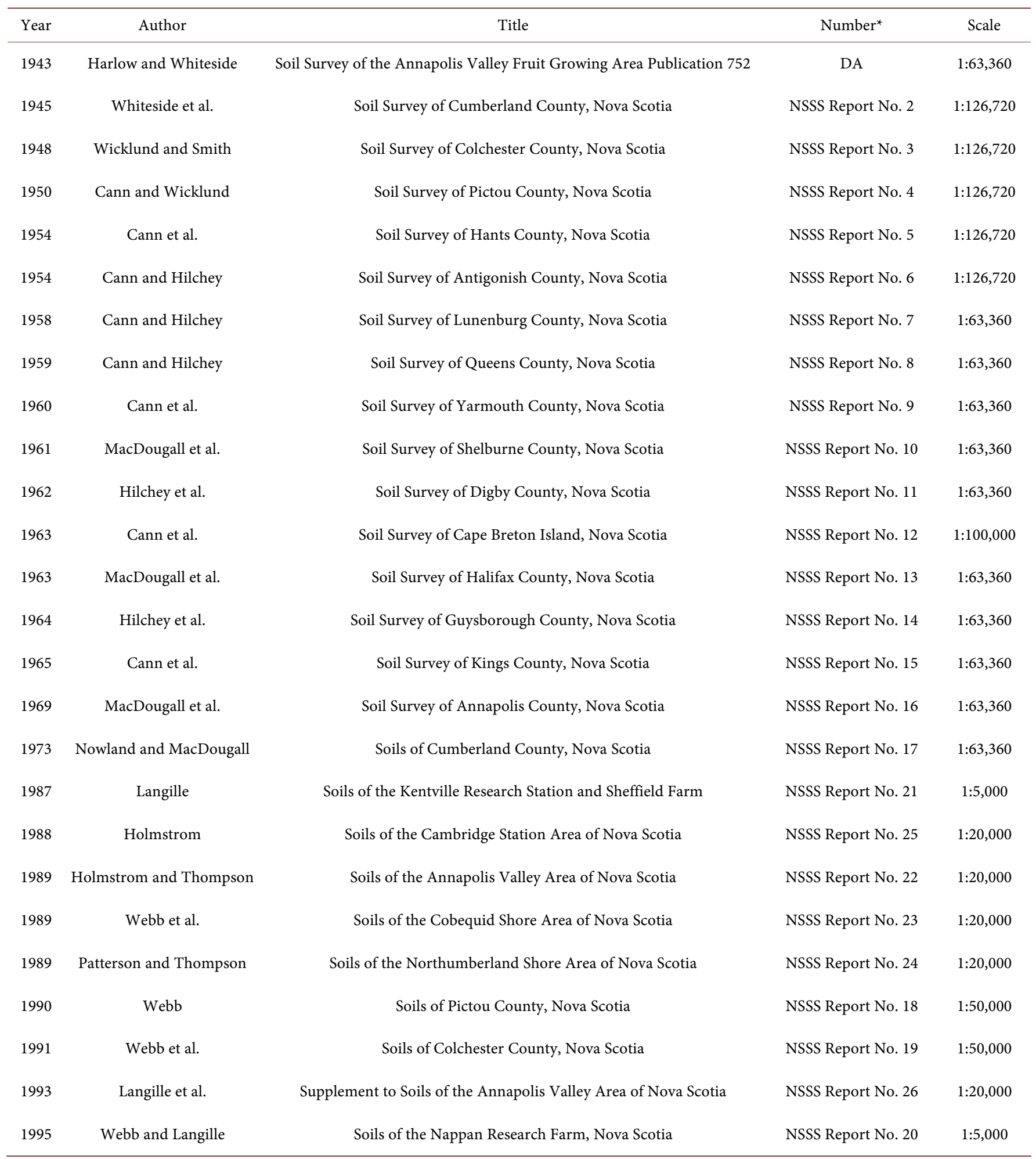

Notes: Surveys from 1943-1973 were published by Canada Department of Agriculture. Surveys from 1987-1995 were published by Agriculture Canada Canada Department of Agriculture (DA) Publication 752 is also recognized as Nova Scotia Soil Survey (NSSS) Report No. 1. 


\section{Appendix 2}

Bolewood density (Gonzalez, 1990), stem to compartment biomass conversion coefficients A and B (Noseworthy, 2011), and biomass nutrient concentrations (Pardo et al., 2005) for plantation and common tree species in Nova Scotia.

\begin{tabular}{|c|c|c|c|c|c|c|c|c|}
\hline Species & $\begin{array}{l}\text { Bolewood Density } \\
\quad\left(\mathrm{g} \cdot \mathrm{cm}^{-1}\right)\end{array}$ & $\begin{array}{c}\text { Biomass } \\
\text { Compartment }\end{array}$ & A & B & $\begin{array}{c}\mathrm{N} \\
\left(\mathrm{mg} \cdot \mathrm{kg}^{-1}\right)\end{array}$ & $\begin{array}{c}\mathrm{Ca} \\
\left(\mathrm{mg} \cdot \mathrm{kg}^{-1}\right)\end{array}$ & $\begin{array}{c}\mathrm{Mg} \\
\left(\mathrm{mg} \cdot \mathrm{kg}^{-1}\right)\end{array}$ & $\begin{array}{c}\mathrm{K} \\
\left(\mathrm{mg} \cdot \mathrm{kg}^{-1}\right)\end{array}$ \\
\hline White/Norway & 0.393 & Bolewood & 0.8174 & 0.0249 & 654 & 943 & 101 & 343 \\
\hline \multirow[t]{3}{*}{ spruce } & & Bark & 0.2641 & -0.2504 & 3560 & 12,949 & 666 & 2418 \\
\hline & & Branches & 0.6443 & -0.4703 & 3750 & 5851 & 514 & 2503 \\
\hline & & Foliage & 3.6451 & -1.0856 & 10,526 & 10,532 & 919 & 5247 \\
\hline \multirow[t]{4}{*}{ Black spruce } & 0.445 & Bolewood & 0.8172 & 0.0248 & 630 & 874 & 138 & 342 \\
\hline & & Bark & 0.2621 & -0.2470 & 2400 & 9966 & 555 & 1542 \\
\hline & & Branches & 0.4762 & -0.4060 & 2592 & 3996 & 430 & 1352 \\
\hline & & Foliage & 2.8232 & -1.0756 & 8372 & 7045 & 893 & 4238 \\
\hline \multirow[t]{4}{*}{ Red spruce } & 0.425 & Bolewood & 0.8458 & 0.0172 & 640 & 690 & 96 & 220 \\
\hline & & Bark & 0.1881 & -0.1734 & 2773 & 6685 & 445 & 1635 \\
\hline & & Branches & 0.0043 & 1.0108 & 2738 & 3381 & 442 & 1826 \\
\hline & & Foliage & 0.0564 & 0.1571 & 10,187 & 4084 & 970 & 5446 \\
\hline \multirow[t]{4}{*}{ Balsam fir } & 0.367 & Bolewood & 0.8257 & 0.0080 & 918 & 823 & 204 & 921 \\
\hline & & Bark & 0.1778 & -0.0466 & 4616 & 7394 & 636 & 2566 \\
\hline & & Branches & 0.1082 & 0.1456 & 3919 & 3812 & 505 & 2569 \\
\hline & & Foliage & 0.8350 & -0.7255 & 12,746 & 7497 & 806 & 4222 \\
\hline \multirow[t]{4}{*}{ White pine } & 0.365 & Bolewood & 0.8426 & 0.0085 & 780 & 516 & 101 & 324 \\
\hline & & Bark & 0.1623 & -0.0586 & 3544 & 4223 & 613 & 1473 \\
\hline & & Branches & 0.0473 & 0.3387 & 4088 & 3034 & 573 & 1946 \\
\hline & & Foliage & 0.2400 & -0.3249 & 12,779 & 2827 & 1154 & 4469 \\
\hline \multirow[t]{4}{*}{ Sugar maple } & 0.702 & Bolewood & 0.7962 & 0.0328 & 976 & 1301 & 198 & 691 \\
\hline & & Bark & 0.3820 & -0.3560 & 5114 & 22,280 & 600 & 3119 \\
\hline & & Branches & 0.1998 & 0.0940 & 3365 & 6313 & 390 & 2101 \\
\hline & & Foliage & 0.2379 & -0.5871 & 19,486 & 9337 & 1537 & 7551 \\
\hline \multirow[t]{4}{*}{ Red maple } & 0.586 & Bolewood & 0.8281 & 0.0226 & 885 & 1121 & 204 & 803 \\
\hline & & Bark & 0.2377 & -0.2329 & 4332 & 13,016 & 468 & 1985 \\
\hline & & Branches & 0.1429 & 0.1624 & 3092 & 4655 & 421 & 1704 \\
\hline & & Foliage & 0.4206 & -0.8024 & 16,958 & 7638 & 2041 & 6827 \\
\hline \multirow[t]{4}{*}{ Yellow birch } & 0.649 & Bolewood & 0.9169 & -0.0090 & 1026 & 701 & 155 & 433 \\
\hline & & Bark & 0.0911 & 0.0816 & 5672 & 10,283 & 423 & 1243 \\
\hline & & Branches & 0.1447 & 0.2385 & 4600 & 4130 & 363 & 1130 \\
\hline & & Foliage & 0.5310 & -0.7686 & 23,490 & 9624 & 2558 & 10,241 \\
\hline \multirow[t]{4}{*}{ White birch } & 0.588 & Bolewood & 0.8234 & 0.0127 & 924 & 775 & 185 & 514 \\
\hline & & Bark & 0.1875 & -0.0846 & 3639 & 6846 & 413 & 1201 \\
\hline & & Branches & 0.1875 & 0.0633 & 3913 & 4413 & 533 & 1594 \\
\hline & & Foliage & 0.7582 & -0.8548 & 19,165 & 7222 & 2247 & 8645 \\
\hline \multirow[t]{4}{*}{ Trembling aspen } & 0.424 & Bolewood & 0.7881 & 0.0136 & 1298 & 2239 & 343 & 1119 \\
\hline & & Bark & 0.2188 & -0.0665 & 4497 & 12,038 & 1053 & 2631 \\
\hline & & Branches & 0.1042 & 0.0600 & 5046 & 9736 & 1156 & 2767 \\
\hline & & Foliage & 0.3400 & -0.8310 & 21,136 & 10,599 & 2082 & 7813 \\
\hline
\end{tabular}


Submit or recommend next manuscript to SCIRP and we will provide best service for you:

Accepting pre-submission inquiries through Email, Facebook, LinkedIn, Twitter, etc. A wide selection of journals (inclusive of 9 subjects, more than 200 journals)

Providing 24-hour high-quality service

User-friendly online submission system

Fair and swift peer-review system

Efficient typesetting and proofreading procedure

Display of the result of downloads and visits, as well as the number of cited articles

Maximum dissemination of your research work

Submit your manuscript at: http://papersubmission.scirp.org/

Or contact ojf@scirp.org 